\title{
36. PALEOGENE BENTHIC FORAMINIFER BIOSTRATIGRAPHY AND PALEOECOLOGY AT SITE 647, SOUTHERN LABRADOR SEA ${ }^{1}$
}

\author{
M. A. Kaminski, ${ }^{2}$ F. M. Gradstein, ${ }^{2,3}$ and W. A. Berggren ${ }^{4,5}$
}

\begin{abstract}
Benthic foraminifers were examined from the Paleogene of Ocean Drilling Program (ODP) Site 647 and Deep Sea Drilling Program (DSDP) Site 112 in the southern Labrador Sea. The Paleogene sequence of the deep Labrador Sea can be subdivided into seven assemblages, based on the ranges and relative abundance of characteristic taxa. The first occurrences (FOs) and last occurrences (LOs) of important benthic taxa are calibrated to a standard biochronology, by interpolating from our age model for Site 647. The biostratigraphy of Site 647 is used to improve the age estimates of Site 112 cores. Fifteen microfossil events in Site 647 also are found in the sedimentary wedge along the Labrador Margin. A comparison of the probabilistic microfossil sequence from the Labrador Margin with that at Site 647 yields four isochronous benthic foraminifer LOs. Two new species are described from Sites 647 and 112: Hyperammina kenmilleri, Kaminski n.sp., and Ammodiscus nagyi Kaminski n.sp.

Significant faunal turnovers are observed at the Ypresian/Lutetian and Eocene/Oligocene boundaries. The Ypresian/Lutetian boundary is characterized by a Glomospira-facies and is attributed to a rise in the CCD (carbonate compensation depth) associated with the NP14 lowstand in sea level. The Eocene/Oligocene boundary is delimited by the LO of Spiroplectammina spectabilis and Reticulophragmium amplectens. The change from an Eocene agglutinated assemblage to a predominantly calcareous assemblage in the early Oligocene took place gradually, over a period of about $4 \mathrm{Ma}$, but the rate of change accelerated near the boundary. This faunal turnover is attributed to changes in the preservation of agglutinated foraminifers, as delicate species disappeared first. Increasingly poorer preservation of agglutinated foraminifers in the late Eocene to earliest Oligocene reflects the first appearance of cool, nutrient-poor deep water in the southern Labrador Sea. The approximately coeval disappearance of agglutinated assemblages along the Labrador Margin was caused by a regional trend from slope to shelf environments, accentuated by the "mid"-Oligocene lowstand in sea level.
\end{abstract}

\section{INTRODUCTION}

The Labrador Sea played an important role in the early history of the North Atlantic, because it has served as a corridor for the exchange of surface water between the North Atlantic and Arctic oceans, possibly since the Late Cretaceous (Gradstein and Srivastava, 1980). Bipolar climatic cooling and the opening of deep marine connections with the Arctic Ocean through the Norwegian-Greenland Sea has been proposed as a causal mechanism resulting in vigorous deep circulation in the North Atlantic near the Eocene/Oligocene boundary (Miller and Tucholke, 1983). As a consequence of increased oceanic circulation, the Eocene/Oligocene boundary is usually represented by a hiatus in western North Atlantic and Rockall Margin sites; thus, limited data exist on the response of benthic foraminifers to climatic and oceanographic changes at this time. However, results from DSDP Leg 12 in the southern Labrador Sea indicated that a continuous Eocene-Oligocene section is present at the Gloria Drift (Fig. 1). The Gloria Drift lies in the pathway of northernsource deep water, relatively near its presumed source in the Faeroe-Shetland Channel. The stratigraphic record of the Labrador Sea thus provides an opportunity to study the early Cenozoic paleoceanographic history of the North Atlantic and its possible connections with the Arctic Ocean.

\footnotetext{
${ }^{1}$ Srivastava, S. P., Arthur, M., Clement, B., et al., 1989. Proc. ODP, Sci. Results, 105: College Station, TX (Ocean Drilling Program).

2 Centre for Marine Geology, Dalhousie University, Halifax, Nova Scotia B3H 3J5, Canada.

3 Atlantic Geoscience Centre, Bedford Institute of Oceanography, Dartmouth, Nova Scotia B2Y 4A2, Canada.

4 Department of Geology and Geophysics, Woods Hole Oceanographic Institution, Woods Hole, MA 02543.

5 Department of Geology, Brown University, Providence, RI 02912.
}

Paleogene deep-water benthic foraminifer assemblages in high latitudes are composed of predominantly agglutinated taxa, whereas temperate and low-latitude bathyal and abyssal faunas in the Atlantic are mostly calcareous. Drilling during DSDP Leg 12 recovered a mixture of calcareous and agglutinated assemblages at Site 112 (Berggren, 1972; Miller at al., 1982). Therefore, the sediments of the deep Labrador Sea provide a link between low- and high-latitude faunal provinces. Unfortunately, Site 112 was discontinuously cored and sediments spanning major stage boundaries or seismic reflectors were not recovered. Consequently, the geochronology of microfossil events in the Labrador Sea was not firmly established. Earlier studies indicated that a major faunal turnover was associated with the Eocene/Oligocene boundary in the Labrador Sea (Miller et al., 1982), but the timing and rate of change of the microfaunal assemblage was not known.

The primary scientific objectives of Leg 105 benthic foraminifer studies in the Labrador Sea were as follows:

1. To establish the geochronology of benthic foraminifers, to identify and date characteristic assemblages, and to correlate ODP Site 647 with DSDP Site 112 and the Labrador Margin zonation of Gradstein et al. (1985).

2. To examine the benthic foraminifera record and to infer changes in deep-water conditions near major stage boundaries and the development of psychrospheric conditions in the early Oligocene.

3. To determine the relationship of faunal changes to regional seismic horizons.

Here, we develop a high-latitude Paleogene biochronology, compare the stratigraphy of Site 647 with the sequence of microfossil events on the Labrador Margin, identify isochronous 


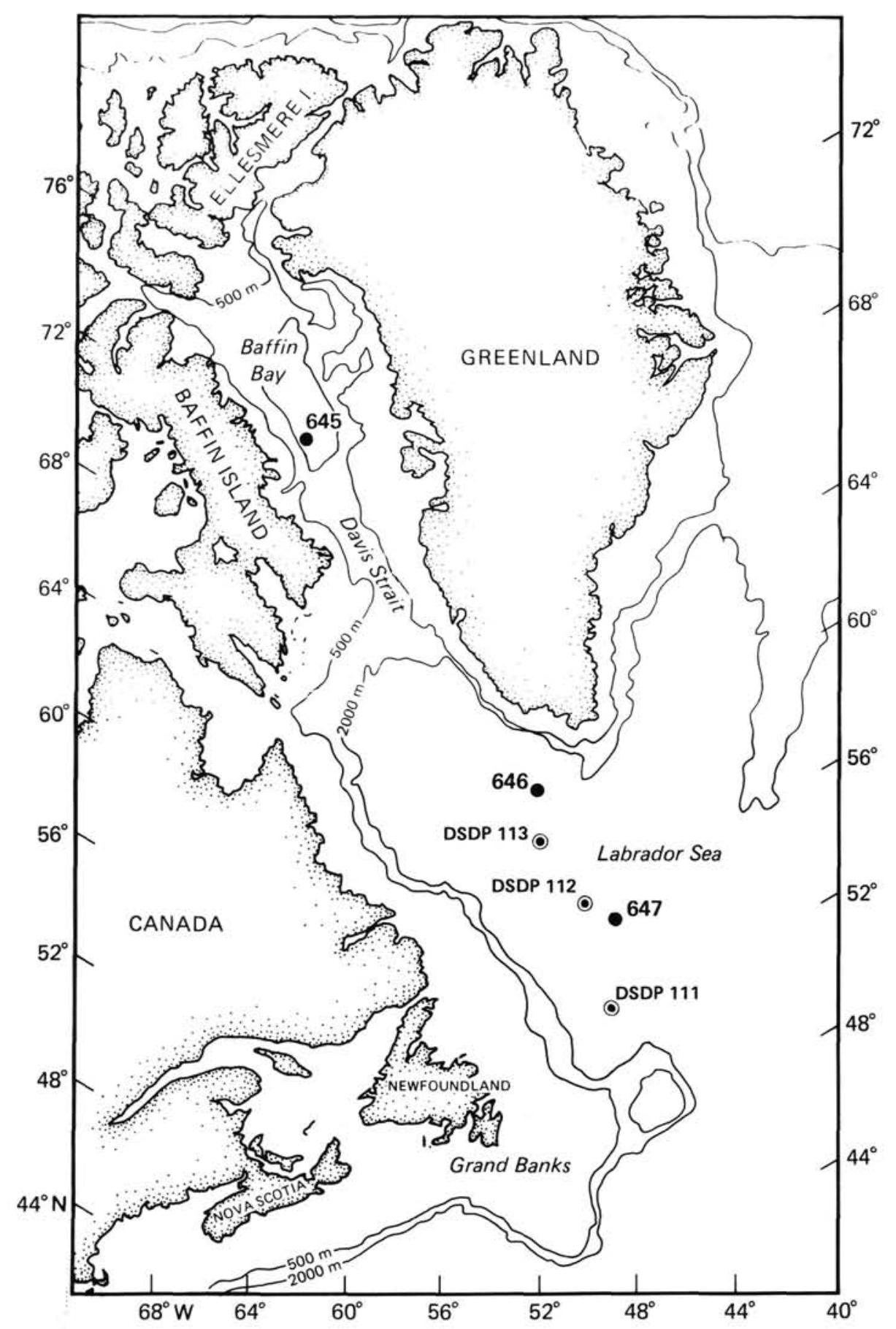

Figure 1. Location of DSDP and ODP sites in the Labrador Sea and exploration wells on the Labrador Margin.

microfossil events, and examine the distribution of benthic foraminifers along a paleobathymetric gradient from the margin to abyssal depths. In addition to the previously mentioned objectives, we compare faunas from Site 647 with those recovered from exploration wells along the Labrador Margin and northern Grand Banks and from DSDP sites in the North Atlantic and Norwegian-Greenland Sea to delineate first-order patterns in benthic foraminifer paleobiogeography. Studies of faunal similarity and migrations of taxa between basins are essential for understanding the history of arctic vs. antarctic sources for deepwater masses in the early Cenozoic.

\section{SAMPLE LOCALITY}

Site 647 was drilled at a water depth of $3861.8 \mathrm{~m}$ in the southern Labrador Sea $\left(53^{\circ} 19.8^{\prime} \mathrm{N}, 46^{\circ} 15.7^{\prime} \mathrm{W}\right)$ on oceanic crust of Chron C24 age. The site is located approximately $90 \mathrm{~km}$ southeast of Site 112 (Fig. 1) on the southeast flank of the Gloria Drift, a depositional feature formed by bottom currents that 
originate in the Norwegian-Greenland Sea. Two holes were drilled at Site 647 . Hole $647 \mathrm{~A}$ penetrated $580 \mathrm{~m}$ of Paleogene sediments, which were subdivided into four lithologic units (Fig. 2). Only Neogene sediments were recovered from Hole 647B, and these are not examined here.

Four major seismic reflectors are evident in multichannel seismic lines and in downhole logging records from Hole 647A (see "Site 647," Srivastava, Arthur, et al., 1987). The R2 reflector corresponds to a hiatus between upper Miocene nannofossil clay and lower Miocene siliceous silty clays. The prominent regional seismic reflector R3-R4 corresponds to lithologic changes bracketing a unit of porous siliceous nannofossil clays and clayey diatomite between 212 and 241 meters below seafloor (mbsf). There is no evidence of a hiatus at either of these reflectors. The R4 reflector corresponds to the previous identification of this reflector at Site 112 and seems to have no relationship to changes in bottom-water circulation.

Two intra-Eocene reflectors are visible near the base of the sediment sequence at Site 647 . The first reflector, at approximately $525 \mathrm{mbsf}$, appears to correspond in depth with the base of lithologic Unit IIIC (Fig. 2). The second, at a calculated depth of 618 mbsf, occurs near a sudden change in carbonate content corresponding to a condensed interval and/or a hiatus separating the middle and lower Eocene.

\section{METHODS}

Shipboard core-catcher samples from Hole 647A were processed according to standard laboratory techniques. The $20-\mathrm{cm}^{3}$ samples from Hole $647 \mathrm{~A}$ and samples from Site 112 were processed onshore following a procedure developed by M. A. Kaminski, M. J. Head, and D. B. Lazarus to separate foraminifers from other microfossils. First, samples were dried overnight at $60^{\circ} \mathrm{C}$ and then weighed to provide data on absolute abundance. Samples containing siliceous microfossils were partitioned into two parts. One-half the sample was disaggregated in a solution of $1 \%$ Calgon and sieved over a $38-\mu \mathrm{m}$ sieve. The residue of this half of the sample was dried, dry-sieved over a $125-\mu \mathrm{m}$ screen, and foraminifers were selected from the $>125-\mu \mathrm{m}$ fraction. The remaining $>125-\mu \mathrm{m}$ residue was combined with the $38-$ to $125-\mu \mathrm{m}$ fraction and was used for radiolarian analyses.

The remaining one-half of the original $20-\mathrm{cm}^{3}$ sample was processed for foraminifers and palynomorphs. Distilled water was used at all times to minimize contamination. The sample was disaggregated in a $1 \% \mathrm{Cal}-$ gon solution and sieved through a $63-\mu \mathrm{m}$ sieve that was placed over a $1000-\mathrm{mL}$ Nalgene beaker to save the washthrough. A wash-bottle was used to rinse the sample carefully until all clay and silt was washed through the sieve. The $>63-\mu \mathrm{m}$ fraction was rinsed into a drying pan and examined for palynomorphs. If these were present, distilled water was added to the residue, agitated, and decanted into a $1000-\mathrm{mL}$ washthrough beaker until all light organic particles were decanted.

The beaker was covered with plastic wrap and allowed to settle one week, after which the decantate was siphoned off. The remaining sediment was transferred into Nalgene sample jars and sent to Martin Head at the University of Toronto for further processing for dinoflagellates. The $>63-\mu \mathrm{m}$ fraction was dried, dry-sieved using a $125-\mu \mathrm{m}$ sieve, and benthic foraminifers were selected from the $>125-\mu \mathrm{m}$ fraction. These benthic foraminifers were combined with the specimens already selected from the radiolarian preparations, and specimens were mounted on cardboard slides for quantitative analysis.

For this study, a total of 124 samples from Hole $647 \mathrm{~A}$ were quantitatively picked for benthic foraminifers; the faunal census is given in the Appendix. Faunal data (raw counts and percentage abundance) also are available from M. Kaminski in Lotus 123 (.WK1) format on 360k MSDOS floppy disks. Each sample's age was interpolated from the sedimentation-rate curve (see "Site 647," Srivastava, Arthur, et al., 1987). From intervals having full recovery, we examined three samples per core, which yields a sample resolution of approximately one sample per 100 k.y. This level of resolution was achieved across the Eocene/Oligocene boundary and throughout most of the upper and upper-middle Eocene.

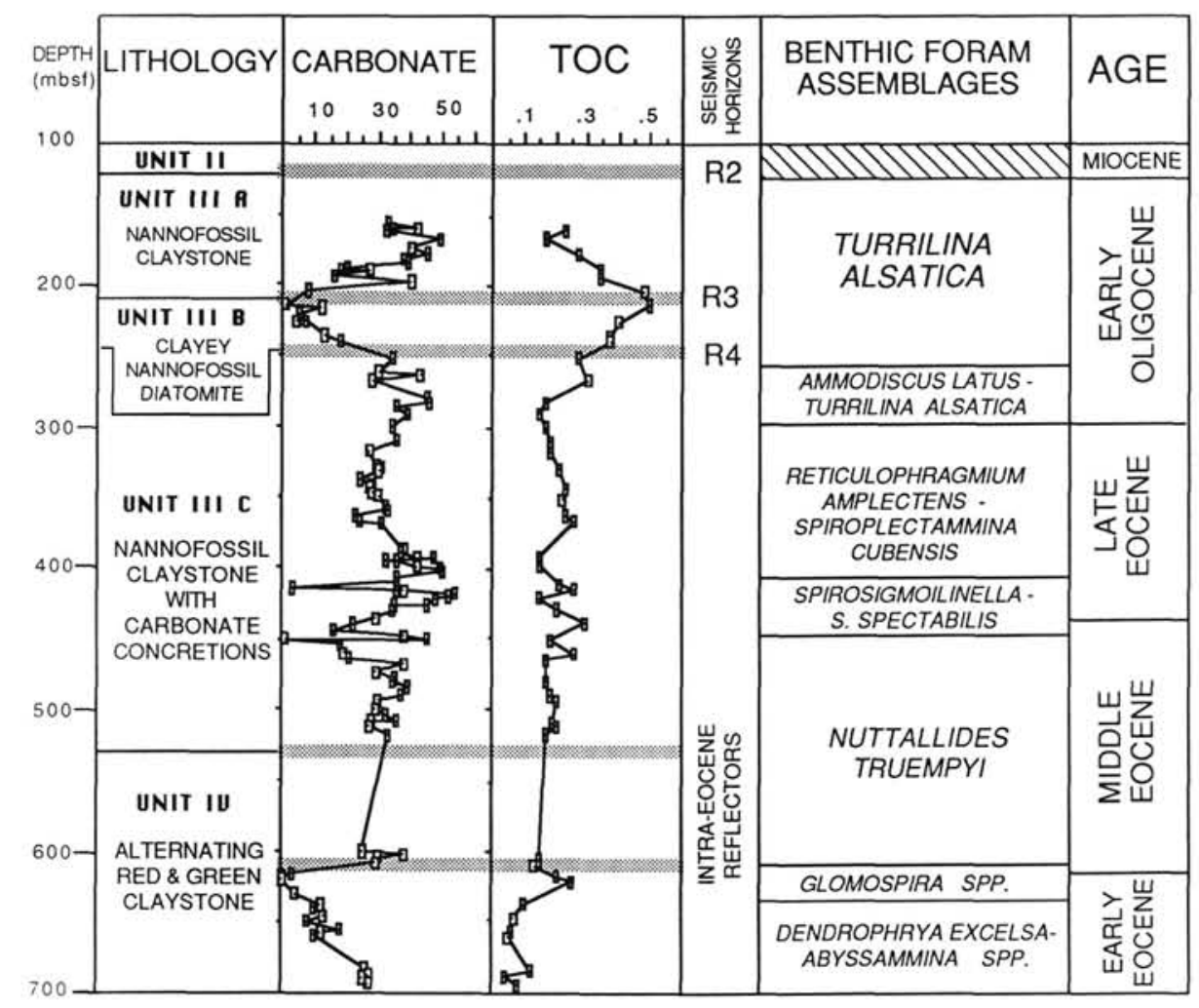

Figure 2. Comparison of lithostratigraphy, midsediment seismic reflectors, percentage of carbonate and total organic carbon content with benthic foraminifer biochronology in the Paleogene of Site 647. Depth to reflectors and lithologic data are taken from the "Site 647" chapter (Srivastava, Arthur, et al., 1987). 


\section{RESULTS \\ Biostratigraphy}

The biochronology of Hole 647A is constrained by calcareous nannofossils, planktonic foraminifers, diatoms, radiolarians, and palynomorphs. In addition, the identification of anomaly 15 correlative magnetic reversals allows us to calibrate the age-depth curve to a standard geochronology (Berggren et al., 1985), and determine the chronology of benthic foraminifer FO and LO events (Table 1). A list of microfossil datums used to establish the chronology of Hole 647A can be found in the "Sedimentation Rates" section of "Site 647" (Srivastava, Arthur, et al., 1987). This chronology has been refined by Firth (this volume), and we use his biochronology across the early/middle Eocene boundary. By interpolation from the sedimentation-rate curve, the Eocene/Oligocene boundary was placed at $290 \mathrm{mbsf}$ and the middle/late Eocene boundary at 410 mbsf. A hiatus, or condensed section, separating sediments of early Eocene and

Table 1. Estimated chronologic ages of benthic microfossil events in Site 647, based on the age model used for the sedimentation-rate curve (Srivastava, Arthur, et al., 1987).

\begin{tabular}{|c|c|c|}
\hline Taxon & $\begin{array}{l}\text { Depth } \\
\text { (mbsf) }\end{array}$ & $\begin{array}{c}\text { Age } \\
\text { (Ma) }\end{array}$ \\
\hline LO Turrilina alsatica & 155.9 & 31 \\
\hline LO Bathysiphon sp. & 251.2 & 35.5 \\
\hline LO Glomospira charoides & 251.1 & 35.5 \\
\hline LO Ammodiscus latus & 251.1 & 35.5 \\
\hline LO Nuttallides umbonifera & 262.7 & 35.8 \\
\hline LO Ammodiscus cretaceous & 280.5 & 36.3 \\
\hline LO Osangularia mexicana & 280.5 & 36.3 \\
\hline LO Gavelinella micra & 280.5 & 36.3 \\
\hline LO Bolivina huneri & 281.4 & 36.4 \\
\hline LO GIomospira irregularis & 285.0 & 36.5 \\
\hline LO Recurvoides spp. & 290.3 & 36.6 \\
\hline LO Reticulophragmium amplectens & 290.3 & 36.6 \\
\hline LO Spiroplectammina spectabilis & 290.3 & 36.6 \\
\hline LO Ammolagena clavata & 290.3 & 36.6 \\
\hline LO Trochammina deformis & 290.3 & 36.6 \\
\hline LO Ammobaculites aff. polythalamus & 290.3 & 36.6 \\
\hline LO Subreophax scalaria & 290.3 & 36.6 \\
\hline LO Saccammina complanata & 290.8 & 36.6 \\
\hline LO Glomospira serpens & 290.8 & 36.6 \\
\hline LO Trochamminoides irregularis & 290.8 & 36.6 \\
\hline LO Rhizammina spp. & 300.3 & 36.9 \\
\hline LO Haplophragmoides walteri & 300.3 & 36.9 \\
\hline LO Reophax pilulifer & 318.0 & 37.4 \\
\hline LO Gavelinella capitata & 318.0 & 37.4 \\
\hline LO Cibicidoides grimsdalei & 328.4 & 37.6 \\
\hline LO Hyperammina kenmilleri n.sp. & 329.9 & 37.7 \\
\hline LO Bulimina macilenta & 329.9 & 37.7 \\
\hline LO Karreriella coniformis & 331.4 & 37.7 \\
\hline LO Bigenerina sp. & 331.4 & 37.7 \\
\hline LO Reophax guttifer & 339.2 & 380 \\
\hline LO Ammosphaeroidina sp. & 340.7 & 38.0 \\
\hline LO Reticulophragmium placenta & 350.6 & 38.3 \\
\hline LO Hormosina distans & 360.3 & 38.6 \\
\hline LO Glomospira gordialis & 360.3 & 38.6 \\
\hline LO Nuttallides truempyi & 386.0 & 39.2 \\
\hline LO Karreriella conversa & 405.8 & 39.8 \\
\hline FO Spiroplectammina cubensis & 408.8 & 39.9 \\
\hline FO Spirosigmoilinella compressa & 425.8 & 40.4 \\
\hline LO Spiroplectammina spectabilis perplexa & 434.4 & 40.6 \\
\hline LO Spiroplectammina navarroana & 460.3 & 41.3 \\
\hline FO Ammodiscus nagyi n.sp. & 498.3 & 42.4 \\
\hline LO Aragonia spp. & 540.0 & 43.5 \\
\hline LO Cibicidoides subspiratus & 569.1 & 44.3 \\
\hline FO Ammodiscus latus & 578.8 & 44.6 \\
\hline LO Verneuilinoides polystrophus & $578: 8$ & 44.6 \\
\hline LO Dendrophrya ex gr. excelsa & 620.7 & $48.8-52.6$ \\
\hline LO Hormosina ovulum & 627.2 & $48.8-52.6$ \\
\hline LO Abyssammina spp. & 638.6 & $52.6-53.6$ \\
\hline LO Quadrimorphina profunda & 657.5 & 54.2 \\
\hline
\end{tabular}

middle Eocene age is present between 610 and $640 \mathrm{mbsf}$. This hiatus, or condensed interval, corresponds approximately to the position of the lowermost intra-Eocene seismic reflector apparent in multichannel seismic records across the Gloria Drift (Fig. 2; "Site 647," Srivastava, Arthur, et al., 1987). Core recovery between the intra-Eocene seismic reflectors was incomplete, and only core-catcher samples from Cores 105-647A-55R to -61R were available for study.

The lower Eocene to lower Oligocene of Hole 647A can be subdivided into seven assemblages, based on the partial ranges of characteristic benthic taxa. The assemblages were chosen to reflect a subdivision of the sedimentary section at a stage level and are named after taxa that are cosmopolitan and have correlative value in the North Atlantic. These assemblages are shown in Figure 2 and are discussed next, in order from oldest to youngest. The relative proportions of important taxa in the Paleogene section are shown in Figure 3.

1. Dendrophrya ex gr. excelsa-Abyssammina Assemblage (Samples 105-647A-71R-2, 42-45 cm, to -66R-2, 24-27 cm), lower Eocene:

This assemblage is characterized by the presence of the nominate taxa and contains a mixture of agglutinated and calcareous benthics in a Subbotina patagonica planktonic ooze typical of Zones P8 to P9 (Berggren and Schnitker, 1983). Calcareous foraminifers are silicified to some degree. The sediments overlying basement were deposited in a water depth of 1700 to 2000 $\mathrm{m}$, based on estimates using the backtracking method of Sclater et al. (1985). The benthic assemblage displays evidence of a lower bathyal setting; for example, the relative proportion of Lenticulina spp. and Bulimina spp. is higher than in any of the overlying assemblages. The Abyssammina-Dendrophrya assemblage corresponds to nannofossil Zones NP11-NP13 (Firth, this volume).

The nominate taxa are common to abundant in some samples (Fig. 3). Abyssammina makes up $10 \%$ of the assemblage in Sample 105-647A-68R-1, 129-132 cm, and Dendrophrya ex gr. excelsa makes up $37 \%$ of the assemblage in Sample 105-647A$67-1,40-43 \mathrm{~cm}$. Abyssammina spp., Quadrimorphina profunda, Bulimina trinitatensis, and Bulimina cf. semicostata of Tjalsma and Lohmann (1983) are restricted to this assemblage. The latter species is transitional between Bulimina semicostata and $\mathrm{Bu}$ limina glomarchallengeri. An interesting agglutinated species tentatively identified as Hormosina ovulum was found in Samples 105-647A-70R, CC and -64R, CC. This occurrence was unexpected in that $H$. ovulum is not known to occur above the $\mathrm{Pa}$ leocene in bathyal assemblages, and there is no other evidence for reworking.

2. Glomospira Assemblage (Samples 105-647A-65R-2, 31$34 \mathrm{~cm}$, to $-63 \mathrm{R}, \mathrm{CC})$, lower to middle Eocene:

Samples from a $20-\mathrm{m}$ interval represented by Cores $105-$ $647 \mathrm{~A}-64 \mathrm{R}$ and $-65 \mathrm{R}$ are barren of calcareous microfossils, and the benthic foraminifers are present in a "Glomospira facies." The most common species in this interval are Glomospira irregularis, Glomospira charoides, Ammodiscus cretaceous, Karreriella coniformis, Trochamminoides spp., and Haplophragmoides walteri. Depending upon where the base of the Glomospira Assemblage lies in Zone NP13, the assemblage may be as old as 53.6 to $52.8 \mathrm{Ma}$. A Glomospira facies also occurs in "lower Eocene" sediments in the Carpathian Mountain Belt and is usually interpreted as reflecting a pelagic environment at bathyal to abyssal paleodepths. At Site 647 the presence of a Glomospira facies probably results from a rise in the CCD above $2500 \mathrm{~m}$. 
3. Nuttallides truempyi Assemblage (Samples 105-647A-63R-1, $139-142 \mathrm{~cm}$, to $-47 \mathrm{R}-4,74-77 \mathrm{~cm})$, middle Eocene:

This is the interval in Hole 647A between the LO of the carbonate-free claystones containing abundant Glomospira and the FO of Spirosigmoilinella. This assemblage is characterized by the common occurrence of the nominate taxon (Fig. 3). The lower portion of the assemblage corresponds to an interval of poor recovery between Samples 105-647A-54R, CC and -61R, CC. This interval was placed in the middle of Zone NP15 (Zones CPl3b-CP13C of Okada and Bukry, 1980) by Firth (this volume), which corresponds to an age between 48.7 and 47.0 Ma. The $N$. truempyi Assemblage therefore overlies a condensed section and/or a hiatus encompassing the uppermost lower Eocene and the lower-middle Eocene. The species Cibicidoides subspiratus (Nuttall) was found in Samples 105-647A-61R, CC, $-60 \mathrm{R}, \mathrm{CC}$ and $-59 \mathrm{R}, \mathrm{CC}$. This is a distinctive taxon in the Atlantic, owing to its restricted stratigraphic range (Zones P9-P13; Van Morkhoven et al., 1986). The LO of Aragonia spp. occurs between Samples 105-647A-55R, CC and -56R, CC. This event was placed at the top of Zone P14 by Tjalsma and Lohmann (1983), but it apparently occured earlier in the Labrador Sea. Above Core 105-647A-55R, recovery was more or less continuous, and Nuttallides treumpyi decreases in relative abundance. Core 105-647A-54R was placed in nannofossil Zone NP16 by Firth (this volume), and interpolation from the sedimentationrate curve yields an age of $45.5 \mathrm{Ma}$.

The agglutinated component composes approximately $80 \%$ of the benthic assemblage between Cores 105-647A-55R and $-46 \mathrm{R}$. Tubular species are dominant, but Reticulophragmium amplectens and Recurvoides spp. attain their maximum relative abundance in this interval. A number of important stratigraphic events also occur (Fig. 4). These are the FO of Ammodiscus latus in Sample 105-647A-52R-2, 45-48 cm; the LO of Ammodiscus nagyi $\mathrm{n} . \mathrm{sp}$. in Sample 105-647A-52R-5, 54-57 cm, and the LO of Spiroplectammina navarroana in Sample 105-647A-49R$6,117-120 \mathrm{~cm}$. In the North Sea, the LO of $S$. navarroana usually occured earlier, in the lower Eocene (Gradstein et al., 1988).

4. Spiroplectammina spectabilis-Spirosigmoilinella Assemblage (Samples 105-647A-46R-5, 60-63 cm, to -43R-5, 97-100 $\mathrm{cm})$, middle-upper Eocene:

This interval in Hole 647A is defined by the partial range of Spirosigmoilinella, from its FO to the FO of Spiroplectammina cubensis. The assemblage is characterized by the acme of the Spiroplectammina spectabilis plexus (Fig. 3). This interval corresponds to the uppermost part of middle Eocene nannofossil zone NP17, and the lowermost upper Eocene. The exact position of the middle/late Eocene boundary, however has not been determined. Nannofossil stratigraphy (Firth, this volume) places the boundary within Core 105-647A-46R, but interpolation from the sedimentation rate curve places the boundary in Core 105-647A-43R. Our age model yields an age for this assemblage between 40.4 and $39.9 \mathrm{Ma}$.

Two important stratigraphic events are associated with the $S$. spectabilis-Spirosigmoilinella Assemblage (Fig. 4). The LO of the small, compressed variety of Spiroplectammina spectabilis (S. spectabilis perplexa of Kaminski, 1984) occurs in Sample 105-647A-46R-1, 60-63 cm. The last common occurrence (LCO) of $S$. spectabilis spectabilis occurs in Sample 105-647A43R-3, 104-107 cm. This event occurs approximately $1 \mathrm{~m}$ above the middle/late Eocene boundary, as determined from the sedimentation-rate curve. Above this level, the abundance of $S$. spectabilis in our samples never exceeds $10 \%$.
5. Reticulophragmium amplectens-Spiroplectammina cubensis Assemblage (Sample 105-647A-43R-3, 104-107 cm, to -31R-1, $132-135 \mathrm{~cm})$, upper Eocene:

Within the accuracy of our microfossil and magnetic chronology, the interval represented by this assemblage encompasses the entire upper Eocene. The assemblage is defined by the concurrent range of $R$. amplectens and $S$. cubensis. The FO of $S$. cubensis (in Sample 105-647A-43R-3, 104-107 cm) occurs at about the same level as the LCO of S. spectabilis, so the latter event can also be used to determine the base of the interval. The LO of $R$. amplectens in Sample 105-647A-31R-1, 132-135 cm, occurs within $1 \mathrm{~m}$ of the Eocene/Oligocene boundary, which was placed at $290 \mathrm{mbsf}$ according to our age-depth model.

Within this interval, there is a gradual transition from an agglutinated assemblage to a predominantly calcareous assemblage in the Oligocene. A number of typical Eocene taxa, such as Nuttallides truempyi, Cibicidoides grimsdalei, and many of the "flysch-type" agglutinated taxa, have their LOs in this assemblage. This is particularly apparent in Cores 105-647A-32R and $-31 R$, which contain the LOs of 10 agglutinated taxa (Fig. 4). The interval can be further subdivided into a lower and upper portion, based on the extinction of Ammosphaeroidina, Bulimina macilenta, C. grimsdalei, and Karreriella coniformis between Cores 105-647A-35R and -37R. The LO of $N$. truempyi in Sample 105-647A-41R-1, 58-61 cm, is another important extinction event, which corresponds to an approximate age of 39 Ma.

Throughout the interval, the assemblage is still numerically dominated by tubular agglutinated species. In the upper portion of the assemblage, the rectilinear calcareous group (Stilostomella, Dentalina, nodosariids), Pullenia spp., and the " 2 nd Principal Component" of Tjalsma and Lohmann (Cibicidoides, Oridorsalis, Gyroidinoides, and Globocassidulina) become more important.

6. Ammodiscus latus-Turrilina alsatica Assemblage (Samples $105-647 \mathrm{~A}-31 \mathrm{R}-1,132-135 \mathrm{~cm}$, to $-27 \mathrm{R}-1,78-83 \mathrm{~cm}$ :), basal Oligocene:

This interval is defined by the concurrent range of the nominate taxa. The FO of Turrilina alsatica coincides with the LO of $R$. amplectens in Sample 105-647A-31R-1, 132-135 cm. The LO of Ammodiscus latus was observed in Sample 105-647A-27-1, $78-83 \mathrm{~cm}$, but its true LO may be as much as $14 \mathrm{~m}$ higher. Only drilling slurry was recovered in Core 105-647A-26R, which was not sampled for benthic foraminifers. This assemblage corresponds to the basal Oligocene and represents the time interval between $36.6 \pm 0.05$ and $35.3 \pm 0.2 \mathrm{Ma}$.

The species Ammodiscus latus attains its maximum relative abundance in the basal Oligocene (Fig. 3), and Turrilina alsatica is also a common species in many samples. A "flood" of Nuttallides umbonifera was observed in Sample 105-647A-30R-5, $10-13 \mathrm{~cm}(36.5 \pm 0.05 \mathrm{Ma})$, where it makes up $56 \%$ of the total assemblage. The increased abundance of $N$. umbonifera has also been observed in the basal Oligocene of the southern $\mathrm{Pa}$ cific Site 277 (Corliss, 1979) and eastern Atlantic Site 119 (Miller, 1983), which suggests that this event may be useful for interbasinal correlation. Within this interval, the agglutinated foraminifers display a noticable reduction in size, and most of the remaining flysch-type taxa (Glomospira charoides, Bathysiphon sp., Reophax spp., Ammodiscus cretaceous, and Glomospira irregularis) have their LOs. Throughout much of the interval, the benthic assemblage is numerically dominated by rectilinear calcareous taxa, the "2nd Principal Component" taxa, and Pulle- 


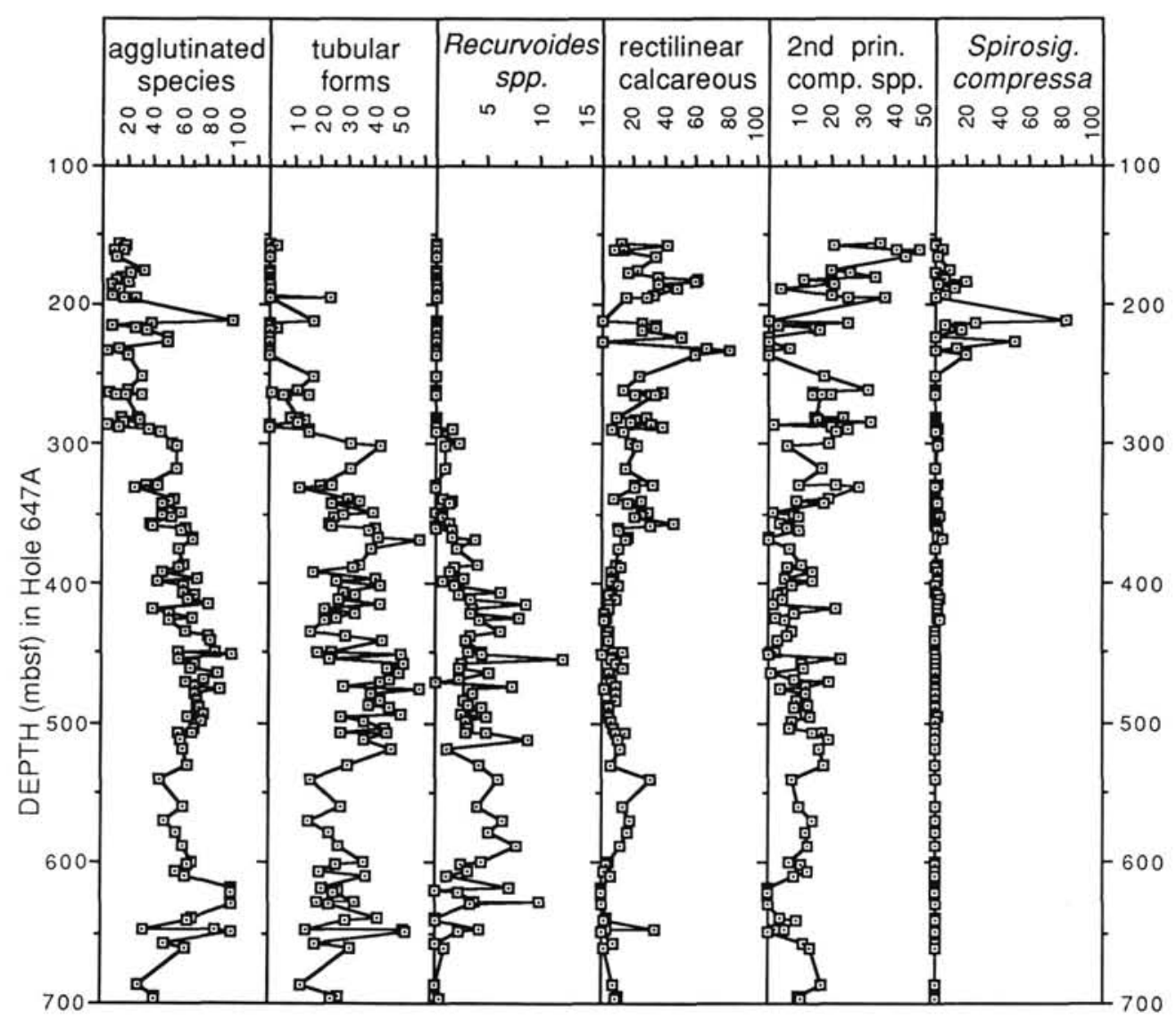

Figure 3. A. Relative abundance of important benthic foraminifer species. B. Species groups in Site 647.

nia spp. This assemblage corresponds to the "Stilostomella Assemblage" of Miller et al. (1982) at Site 112.

7. Turrillina alsatica Assemblage (Sample 105-647A-25R-4, $107-110 \mathrm{~cm}$, to $-17 \mathrm{R}-1,107-110 \mathrm{~cm})$, lower Oligocene:

This is the interval between the LO of Ammodiscus latus and the top of the Paleogene section in Hole 647A. The upper limit of the Turrillina alsatica Assemblage is truncated by a barren interval and one or more hiatuses above Core 105-647A-17R. In exploration wells drilled on the Labrador Margin, the LO of $T$. alsatica is used to identify the Paleogene/Neogene boundary, but a hiatus encompassing much of the late Oligocene is also present in the area (Gradstein, 1987).

Throughout the interval, the abundance and diversity of benthic taxa is low, and washed residues contain mainly siliceous debris. Many samples in lithologic Unit IIIB contain only rectilinear and unilocular calcareous species, Karreriella, and Spirosigmoilinella. The most characteristic taxa is Spirosigmoilinella compressa, which displays its greatest relative abundance in this relatively depauperate assemblage. However, its absolute abundance in the early Oligocene does not differ noticably from its abundance in the late Eocene. Uvigerina are common in samples from Core 105-647A-20R. This occurrence corresponds to a peak in the total organic carbon (TOC) content of the sediment (Fig. 2), which along with an increase in the flux of biogenic opal possibly indicates high paleoproductivity. Among flysch-type agglutinated taxa, only Cribrostomoides subglobosus and Rhabdammina persist into this assemblage.

\section{DISCUSSION}

\section{Eocene Benthic Foraminifer Paleobiogeography}

The Eocene deep-water benthic foraminifer assemblages of the North Atlantic and adjacent seas can be divided into two end-members, based on the presence or absence of calcareous or agglutinated foraminifers (Fig. 5). Calcareous assemblages are found in low to middle latitudes in DSDP sites and exploration wells along continental margins and in ridge-crest environments. Below or near the oceanic CCD in the equatorial Atlantic, Eocene sediments are barren of foraminifers. The availability of carbonate appears to be a factor controlling the distribution of agglutinated assemblages (Gradstein and Berggren, 1981). Predominantly "flysch-type" assemblages are well developed in high latitudes and in areas where the rapid deposition of clastic sediments creates a benthic environment unfavorable for the preservation of carbonate tests. These assemblages have been found in active margin settings in the Alpine regions and in slope basins in Trinidad (Kaminski et al., 1988), the Labrador Margin and North Sea (Gradstein and Berggren, 1981), as well as in DSDP Sites in the Norwegian-Greenland Sea (Verdenius and van Hinte, 1983). Hole 647A is unique among North Atlantic DSDP and ODP sites, because it is the only hole with a complete record of calcareous and agglutinated benthic foraminifers from the middle Eocene through the early Oligocene.

\section{Comparison of Site 647 Assemblages with Regional Zonations}

Agglutinated foraminifers have been used to define regional zonations for the early Tertiary in the North Sea, Norwegian- 


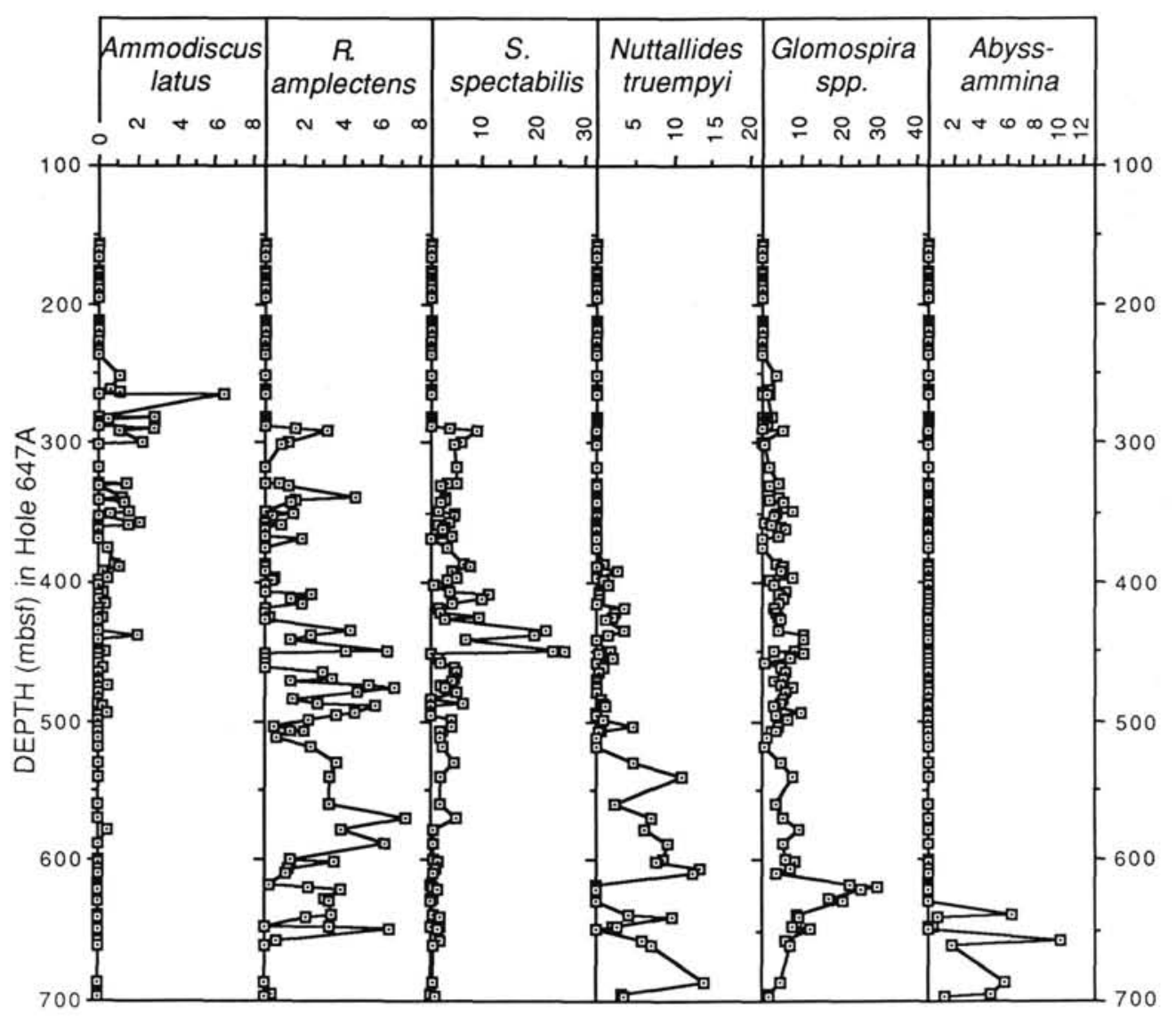

Figure 3 (continued).

Greenland Sea, on the Labrador Margin, as well as in the Polish Flysch Carpathians (Verdenius and van Hinte, 1983; Gradstein and Agterberg, 1982; Geroch and Nowak, 1984; Gradstein et al., 1988). A summary of these zonal schemes is shown in Figure 6. However, in all the regions mentioned above, the task of correlating these zonations to a standard geochronology has been a problem owing to the paucity of calcareous microfossils and lack of magnetic reversal information. Therefore, the biochronology of Hole 647A may serve as a key for correlating the benthic foraminifer stratigraphy of the Labrador Margin to the Norwegian-Greenland and North seas.

The Paleogene Norwegian-Greenland Sea zonation of Verdenius and van Hinte (1983) was based upon DSDP samples collected during Leg 38 . The Eocene/Oligocene boundary in the Leg 38 sites was recognized using the LOs of Spiroplectammina spectabilis and/or Reticulophragmium amplectens. The use of these taxa as Eocene marker species was based on analogies with the Polish Carpathians (Grzybowski, 1898) and the Eocene of Belgium (Kaaschieter, 1961). However, in the Leg 38 samples, calibration of ranges of these taxa to a standard planktonic microfossil chronology was tentative. In Hole 647A, the LO of both taxa was found at $290.3 \mathrm{mbsf}$, in Sample 105-647A-31R-1, $132-135 \mathrm{~cm}$. This sample is just $30 \mathrm{~cm}$ below the position of the Eocene/Oligocene boundary assigned by the paleontologists on Leg 105 (Srivastava, Arthur, et al., 1987).

Both the North Sea and Labrador Margin zonations are made up of RASC (ranking and scaling) interval "zones" based on clusters of LOs of taxa in exploration wells. The RASC biozones are named after characteristic species which most likely have their LOs in the interval, but not necessarily at the top of that interval. Therefore, RASC "zones" reflect the average ranges of taxa, and may differ conceptually from traditional zo- nations, based on maximum ranges of taxa in a given interval. When a RASC optimum sequence is scaled in linear time by the identification of microfossil datum events, "missing intervals" of time become apparent. In the Paleogene Labrador Margin and North Sea zonations, the missing intervals correspond to hiatuses caused by basinward shifts in shoreline (Gradstein, 1987). Reviews of the methodology used in constructing and interpreting RASC zonations can be found in Gradstein et al. (1985), D'Iorio (1986), Gradstein (1987), and Williamson (1987).

The species Reticulophragmium amplectens is perhaps the most distinctive Eocene species in North Atlantic and Tethyan flysch-type assemblages, and it is used as a stratigraphic marker species in every zonal scheme (Fig. 6). Its total range is given as lower to upper Eocene in the Outer Carpathians (Olszewska and Smagowicz, 1977; Morgiel and Olszewska, 1981). Its partial range and optimum occurrence characterizes the middle Eocene Cyclammina amplectens Zone of Geroch and Nowak (1984). In the North Sea, Gradstein et al. (1988) defined a middle to late Eocene $R$. amplectens RASC interval zone based on the partial range of this species. In this region, it was reported to range from the lower Eocene to the Eocene/Oligocene boundary, with possible occurrences in the lower Oligocene. On the Labrador Margin, Gradstein (1985) defined a late Eocene Turborotalia pomeroli-R. amplectens $\mathrm{RASC}$ interval zone. The total range of this species was given as lower to upper Eocene by Miller et al. (1982).

The relative abundance record of $R$. amplectens in Hole 647A is shown in Figure 3. The FO of this taxon was found in Sample 105-647A-70R, CC. This sample has been dated biostratigraphically in the upper part of Zone NP11. The FO of $R$. amplectens in Hole $647 \mathrm{~A}$ is somewhat older than its FO reported in the Subsilesian Unit of the Outer Carpathians in 


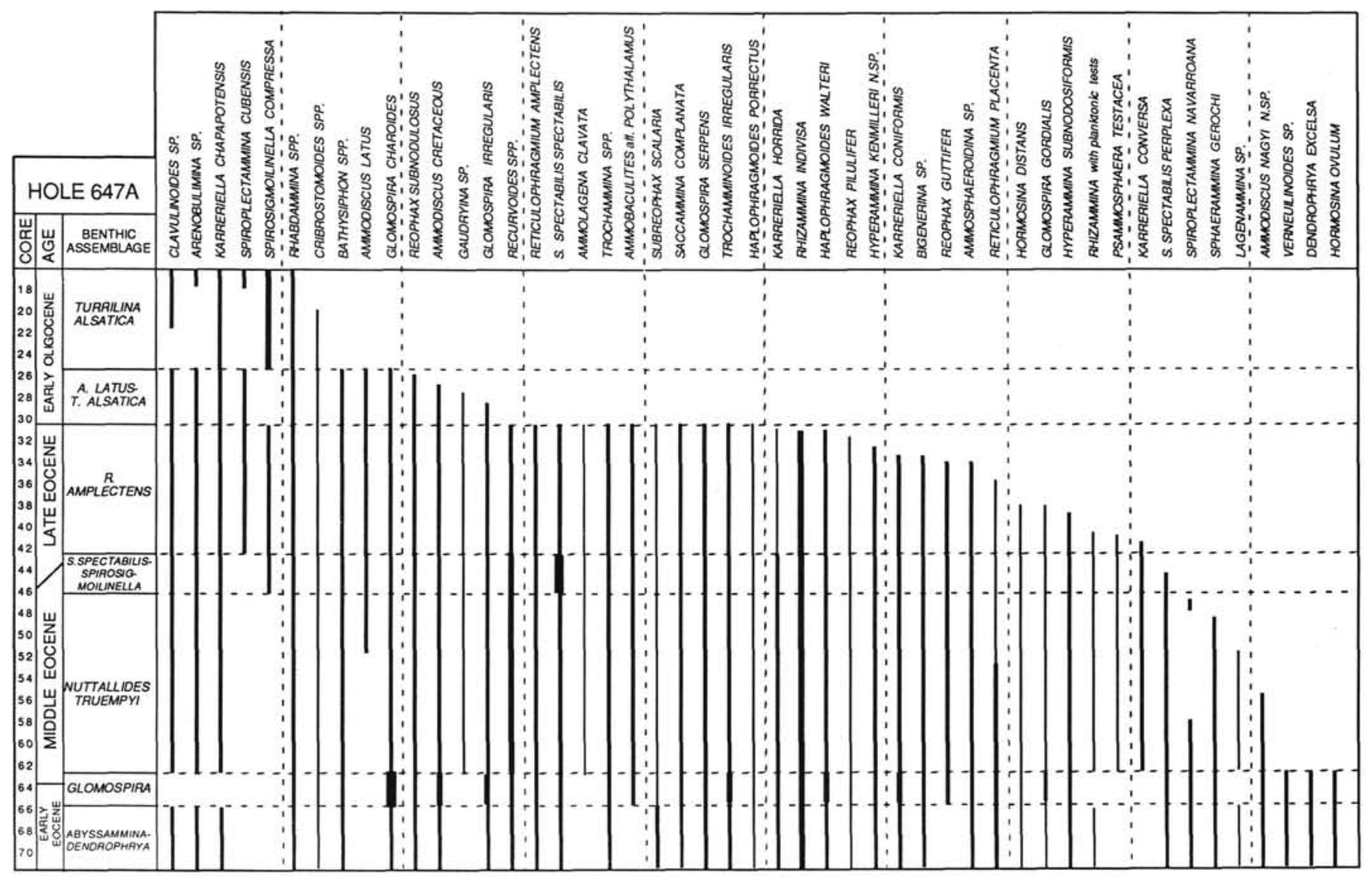

Figure 4. Stratigraphic occurrence of common agglutinated calcareous species in Site 647.

Moravia (Hanzlikova, 1983), where it was first found in the upper part of the $M$. aragonensis Zone (P8). The greatest abundance of $R$. amplectens in Hole 647A occurs in the middle Eocene. In this respect, its occurrence displays similarities with the Carpathian assemblages. The extinction of this species at 36.6 $\mathrm{Ma}$ indicates that it is a reliable indicator of the Eocene/Oligocene boundary in the deep Labrador Sea.

The utility of Spiroplectammina spectabilis as an indicator of the Eocene/Oligocene boundary is probably restricted to abyssal assemblages. In the North Sea and Labrador Margin, the Eocene sequences display a series of LOs of flysch-type taxa that mainly reflect the shallowing of the basins as sediment supply exceeded tectonic subsidence. Spiroplectammina spectabilis disappears from the Labrador Margin in the lower Eocene, but persisted at Site 647 and the deep Norwegian-Greenland Sea until the Eocene/Oligocene boundary. Interestingly enough, in the North Sea, $S$. spectabilis has a diachronous LO in wells aligned from south to north along the axis of the basin (Gradstein et al., 1988).

Upper Eocene assemblages in the North Sea, Poland, and on the Labrador Margin contain the species Ammodiscus latus and Cyclammina rotundidorsata. In the Carpathians, the partial range of the former and the total range of the latter are used to define a late Eocene zone (Fig. 6). However, neither of these species is present in the deep Norwegian-Greenland Sea. $C y$ clammina rotundidorsata was reported by Verdenius and van Hinte (1983) from the Oligocene of Site 345 and the Miocene of Site 348 , but the specimen illustrated by them is not typical of the species, and may have been misidentified. Ammodiscus latus (sensu lato) occurs in both bathyal and abyssal assemblages in the Labrador Sea. The abyssal variety is noticeably smaller than the bathyal variety, and because of this Miller et al. (1982) recorded its occurrence at Site 112 as Ammodiscus rugosus Schijfsma, following Krasheninnikov and Pflaumann (1977). However, A. rugosus is an Upper Cretaceous species known from the epicontinental deposits of Europe (Schijfsma, 1946), and possibly from Site 367 off Morocco (Krashenninikov and Pflaumann, 1977). Because of the restricted stratigraphic occurrence of the "rugose" Ammodiscus in Hole 647A, we believe that this species is a deep-water ecophenotype of $A$. latus. Finding the LO of $A$. latus above the extinction of $R$. amplectens in Hole $647 \mathrm{~A}$ agrees with the relative position of these taxa on the Labrador and northern Grand Banks margins (Fig. 7).

The Oligocene sediments of Norwegian-Greenland Sea sites also contain Spirosigmoilinella, which was used by Verdenius and van Hinte (1983) as a zonal indicator. At Site 338 on the Vøring Plateau, Spirosigmoilinella was not observed below the LO of $S$. spectabilis, or below the LO of $R$. amplectens at Site 345 in the Lofoten Basin. These species were used to determine the Eocene/Oligocene boundary in the Leg 38 Norwegian-Greenland Sea sites (Verdenius and van Hinte, 1983), and both species range to the top of the Eocene in Site 647.

\section{Correlation of Holes $647 \mathrm{~A}$ and 112}

Site 112 is located approximately $90 \mathrm{~km}$ northwest of Site 647 , and until now, constituted the only abyssal Paleogene reference section in the Labrador Sea. A total of six cores containing Paleogene sediments were recovered from this site, and preliminary stratigraphic analysis was conducted by Berggren (1972), Perch-Nielsen (1972), and Bukry (1972). Unfortunately, the Eocene/Oligocene boundary and the position of subsurface seismic reflectors at this site are represented by coring gaps. The 


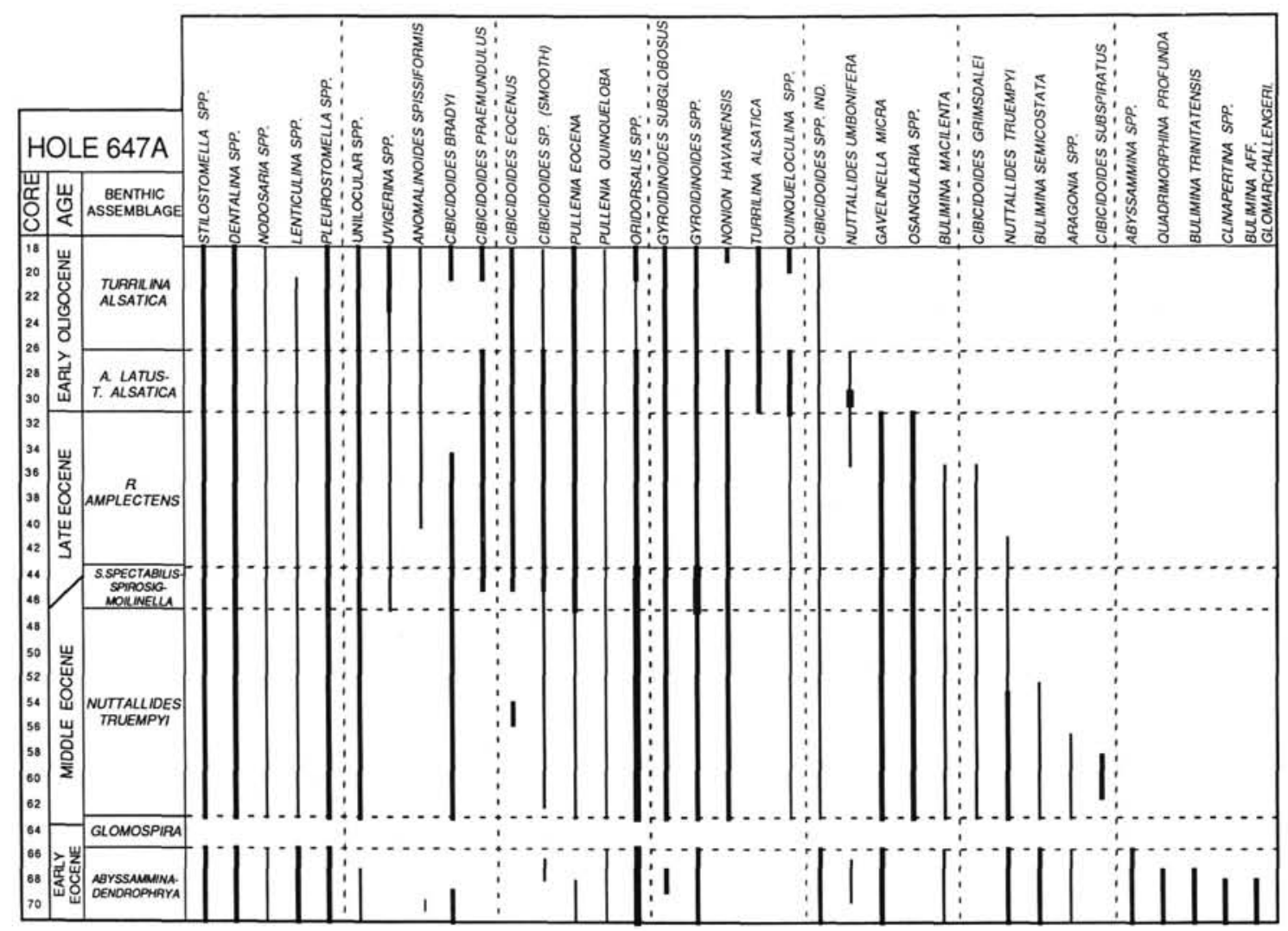

Figure 4 (continued).

foraminifer and nannofossil stratigraphy of Hole 112 was restudied by Miller, Gradstein, Berggren, and Aubry (in Miller et al., 1982), who were able to correlate Cores $12-112-12 R$ to $-15 R$ with standard planktonic microfossil zonations (Table 2).

For this study, we examined benthic foraminifer assemblages from Hole 112 to correlate the position of individual cores from this site with Hole 647A (Fig. 6). Our foraminifer abundance data from Hole 112 are given in the Appendix.

Core 12-112-11R contains a calcareous benthic assemblage belonging to the Turrilina alsatica Assemblage in Hole 647A. The diverse nature of the fauna and good preservation present in Sample 12-112-11R-2, 102-106 cm, is comparable only to the assemblages above the siliceous sediments of lithologic Unit IIIB in Hole 647A. The composition of the assemblage compares best with assemblages from Core 105-647A-17R.

Sample 12-112-12R-1, 44-46 cm, contains a planktonic assemblage with Chiloguembelina, Pseudohastigerina, and Bolboforma irregularis. In Hole 647A, the LO of Chiloguembelina and B. irregularis were found in Sample 105-647A-27R-1, 78-85 $\mathrm{cm}$. However, the only flysch-type agglutinated species present in Sample 12-112-12R-1, 44-46 cm is Rhabdammina sp. The lack of Ammodiscus latus and Glomospira charoides in this sample indicates that it belongs in the Turrilina alsatica Assemblage. The assemblage in this sample probably correlates with the unsampled interval between Cores 105-647A-25R and -27R.

Two samples from Core 12-112-13R were examined for benthic foraminifers (Samples 12-112-13R-3, 118-122 cm, and -13R-5, 120-124 cm). Both samples contain Ammosphaeroidina and Karreriella coniformis, which suggests that Core 12-112-13R correlates with the lower one-half of our $R$. amplectens Assemblage. The position of the assemblage with regard to Hole $647 \mathrm{~A}$ can be further constrained by the absence of $N$. truempyi, and the low abundance of Spiroplectammina spectabilis. This assemblage com- pares well with assemblages from Cores 105-647A-36R through $-40 \mathrm{R}$.

Cores $12-112-14 \mathrm{R}$ and $-15 \mathrm{R}$ correlate with our Nuttallides truempyi Assemblage. We did not find any specimens of Spirosigmoilinella compressa in the two samples from Core 12-112$14 \mathrm{R}$ examined for this study (Samples 12-112-14R-2, 100-104 $\mathrm{cm}$, and 12-112-14R-3, 112-114 cm) but its presence was reported by Miller et al. (1982) from a single sample. In the Spirosigmoilinella-S. spectabilis Assemblage of Hole 647A, however, the occurrence of Spirosigmoilinella is continuous (see Appendix). The assemblage from Core 12-112-14R contains $S$. spectabilis perplexa, Reticulophragmium sp. (evolute), and abundant $N$. truempyi. In addition, the abundance of $S$. spectabilis sensu lato in our samples from Core 12-112-14R does not exceed $6 \%$. This suggests a better correlation with our $N$. truempyi Assemblage. Although Miller et al. (1982) referred the agglutinated component of this core to a "Spiroplectammina spectabilis assemblage," this assemblage does not correlate with our Spirosigmoilinella-S. spectabilis Assemblage (Fig. 6). Core 12$112-15 \mathrm{R}$ belongs in nannofossil Zone NP14 (Miller et al., 1982) and contains poorly preserved calcareous benthic foraminifers that are overgrown with pyrite in a manner analogous to assemblages from Samples 105-647A-56R, CC and -58R, CC. The assemblage in Core 12-112-15R contains Ammodiscus nagyi n.sp., but none of the other species typical of the lower Eocene of Hole 647A (see Fig. 4).

The basal core of Hole 112 was cut approximately $10 \mathrm{~m}$ above basement, which at this site was formed near the boundary between the reversed and normal interval of Chron 26. The indurated red claystones overlying basement are barren of calcareous microfossils. On the Labrador Margin, the Paleocene/ Eocene boundary is determined by the LOs of Gavelinella beccariiformis, Rzehakina epigona, and rare Planorotalides chap- 


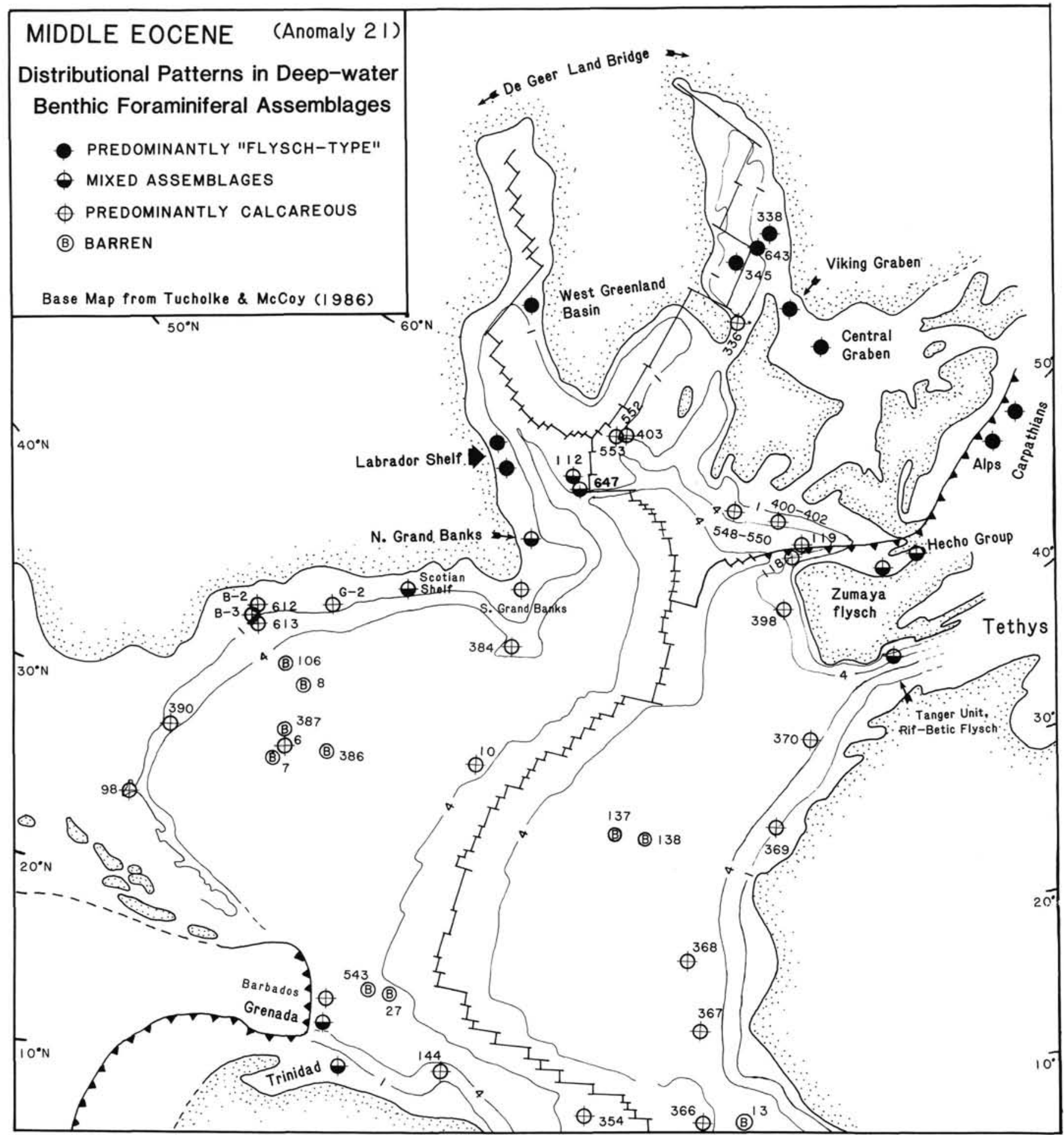

Figure 5. Distribution of agglutinated, calcareous, and mixed benthic foraminifer assemblages in the North Atlantic in the late early to middle Eocene. Data are compiled from site reports, personal observations, and personal communication with J.P. Beckmann, S. Gofas, W. Kuhnt, R. M. Leckie, H. P. Luterbacher, K. G. Miller, L. E. Ostermann, C. W. Poag, A. von Hillebrandt, and M. A. Williamson. Sites that are barren of foraminifers are also shown.

mani. However, the latter species may persist into the lower Eocene in the abyssal western North Atlantic (Tjalsma and Lohmann, 1983). Other species restricted to the Paleocene on the Labrador Margin are Hormosina ovulum, Hormosina excelsa, Saccammina placenta, Tappanina selmensis, and rare Danian planktonics (Subbotina pseudobulloides, S. triloculinoides, Planorotalites compressus).
In Sample 12-112-16R-1, 85-87 cm, we found specimens of Hormosina, but these persist into the lower Eocene of Hole 647A. This sample also contains $R$. epigona, Labrospira pacif$i c a$, and $S$. placenta, species that do not occur in Hole $647 \mathrm{~A}$. In Trinidad and in the North Sea, Labrospira does not occur above the Paleocene. Therefore, we favor a Paleocene age assignment for Core 12-112-16R. 


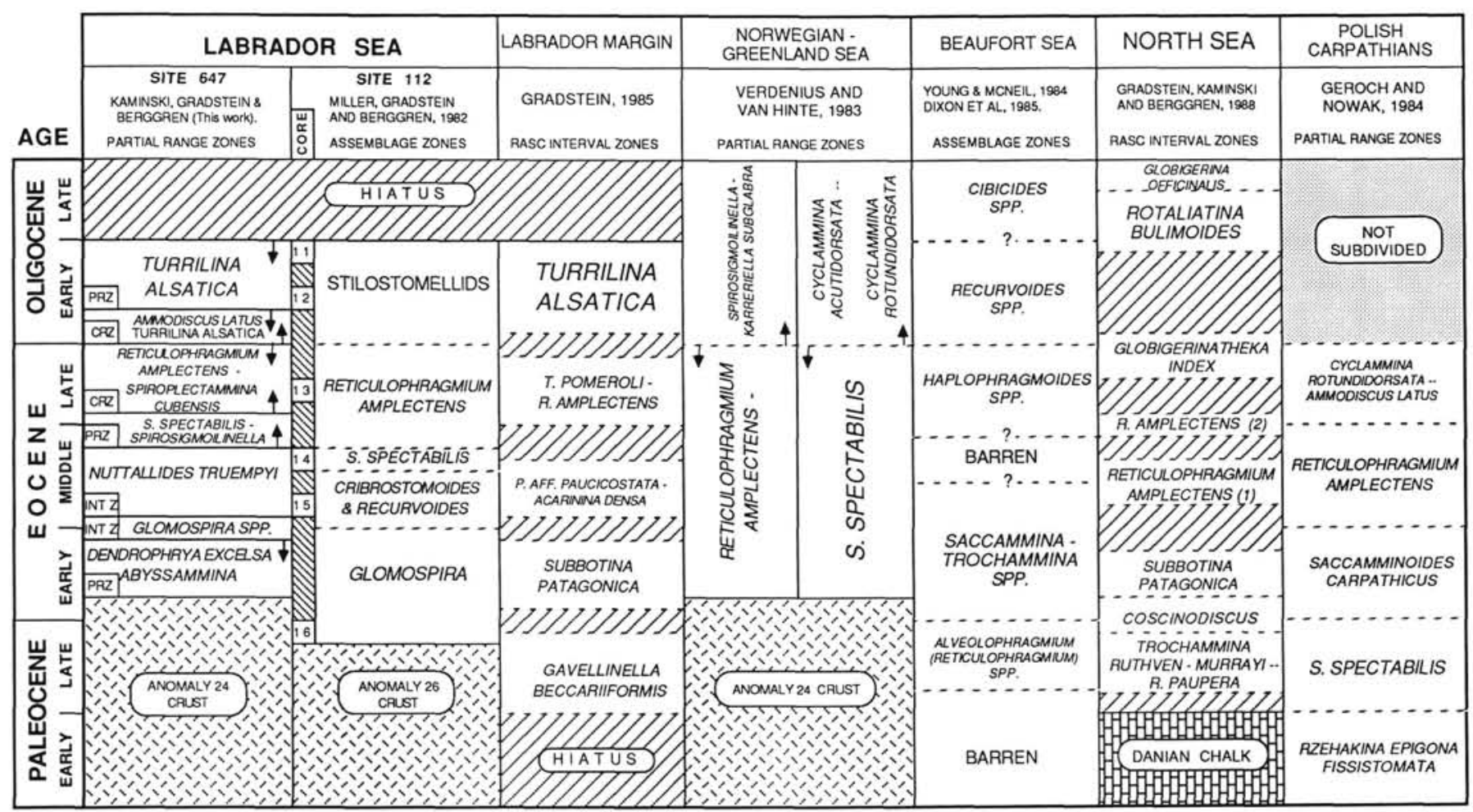

Figure 6. Comparison of Paleogene zonal classifications in areas containing flysch-type assemblages. Correlation of Sites 112 and 647 is from this study. Zonal boundaries that have not been tied to a standard geochronology (Berggren et al., 1985) are indicated by dashed lines. The Labrador Margin and North Sea RASC zonations have been scaled vs. linear time (after Gradstein, 1987) to show the position of stratigraphic breaks.

\section{Correlation of Hole $647 \mathrm{~A}$ with the Labrador Margin}

The benthic foraminifer assemblages from Hole 647A and the Labrador Margin display differences related to paleobathymetry and depositional setting. The Eocene-Oligocene Labrador Margin sequences were deposited in an outer neritic to upper bathyal clastic environment, and abyssal taxa are absent from the benthic foraminifer assemblages. Faunal diversity in samples from exploration wells on the Labrador Margin is noticeably lower than at Site 647 , but a number of important benthic foraminifers occur in both regions, including Turrilina alsatica, Rhabdammina spp., Ammodiscus latus, A. cretaceus, Reticulophragmium amplectens, $R$. placenta, Haplophragmoides walteri, Ammosphaeroidina sp., Reophax pilulifer, Karreriella conversa, $K$. horrida, Spiroplectammina spectabilis, $S$. navarroana, Ammobaculites aff. polythalamus, Glomospira charoides, Trochamminoides spp., and Hormosina ovulum. Few species of calcareous foraminifers are present in the Labrador Margin assemblages, and these are represented mainly by neritic to upper bathyal species of Nodosaria, Lenticulina, Plectofrondicularia, Cibicidoides, and uvigerinids. With the exception of T. alsatica, none of the middle Eocene-Oligocene calcareous species typical of the Labrador Margin were found in Hole 647A. A few of the more offshore wells contain deep-water calcareous species in the lower Eocene, including Nuttallides truempyi.

Figure 7 presents Paleogene RASC benthic foraminifer zones and important benthic taxa in seven wells aligned from south (Adolphus D-50) to north (Karlsefni A-13) on the Labrador Margin. In these wells, several benthic foraminifers possess the same order of LO events. The LOs of T. alsatica, H. walteri, Ammosphaeroidina, and $S$. navarroana do not cross over one another. The LO of Ammodiscus latus, however, appears to be variable with respect to $T$. alsatica. In the Bonavista C-99 and South Labrador N-79 wells, A. latus was found above T. al- satica, but this may be an artifact of sampling. T. alsatica is often a rare species on the Labrador Margin. Reticulophragmium amplectens displays a high crossover frequency with respect to $H$. walteri and Ammosphaeroidina, which suggests a small interfossil distance between them. However, this species appears to intergrade with $R$. placenta in the younger portion of its stratigraphic range, so determining its true LO is sometimes subjective. The LOs of $S$. spectabilis and Glomospira extend to youngest levels in the southern Adolphus D-50 and Blue H-28 wells, but this may be due to the deeper paleobathymetry of these wells. These species are present at younger levels in deeper assemblages.

The probabilistic optimum sequence of microfossil LOs on the Labrador Margin and northern Grand Banks is shown in Figure 8 . This is an ordering based on the average position of extinction events occurring in at least seven of the 23 wells studied. Of the 35 Paleogene extinction events recorded on the Labrador Margin, 15 also were present in Hole 647A. These extinction events are listed across the top of Figure 8 , in a manner analogous to a bivariate scatter plot. The probabilistic $\mathrm{LO}$ of Turrilina alsatica is used to identify the top of the Paleogene sequence on the Labrador Margin. However, the true upper range limit of this event in Hole 647A is most likely truncated by the barren interval and hiatus above Core 105-647A-17R. Microfossil events that extend to younger stratigraphic levels in Hole $647 \mathrm{~A}$ than on the Labrador Margin, plot below a best-fit line between the points.

The most noticeable difference between the Labrador Margin and deep Labrador Sea extinction events is the stratigraphic range of Glomospira charoides (number 56 in Fig. 8). This is a long-ranging taxon that is present in the modern North Atlantic. Its local LO is usually associated with the Paleocene/Eocene boundary on the Labrador Margin and in the southern North Sea, but the taxon extends to the top of the Ammodiscus latusTurrilina alsatica Assemblage (early Oligocene) in Hole 647A. 


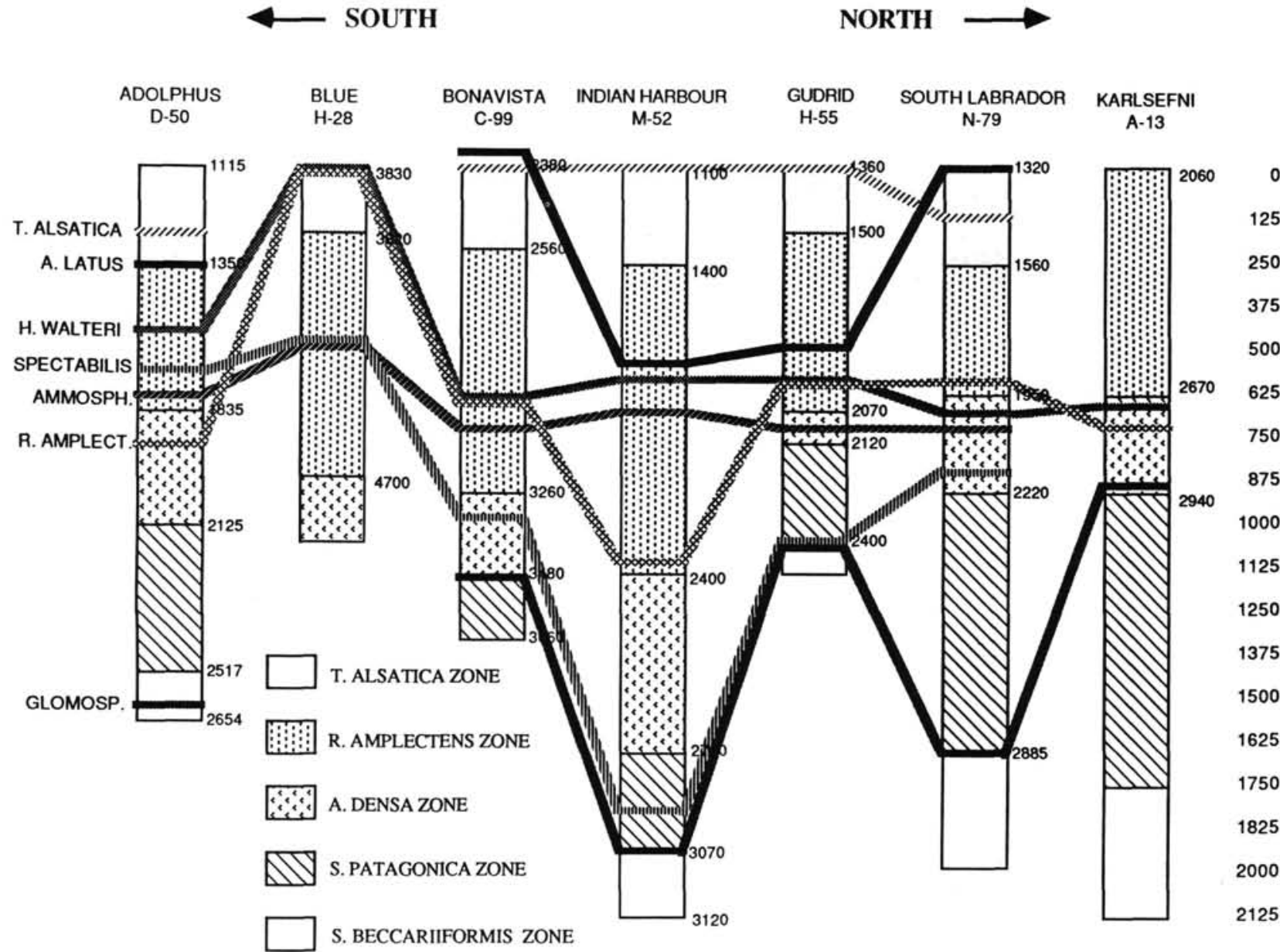

Figure 7. Important benthic foraminifer extinction levels in seven exploration wells on the Labrador Margin. Depth scale on right is thickness of Paleogene sediments (in meters).

Table 2. Paleogene cores from Hole 112.

\begin{tabular}{lcl}
\hline \multirow{2}{*}{$\begin{array}{c}\text { Hole 112 } \\
\text { Core }\end{array}$} & \multicolumn{2}{c}{ Age $^{\mathrm{a}}$} \\
\cline { 2 - 3 } & Nannofossil zone & \multicolumn{1}{c}{ Planktonic zone } \\
\hline $12 \mathrm{R}$ & NP22 & Not diagnostic \\
$13 \mathrm{R}$ & NP19 & P15-P16 \\
$14 \mathrm{R}$ & NP17 & Not older than P14 \\
$15 \mathrm{R}$ & NP14 & P10 \\
$16 \mathrm{R}$ & Barren & Barren \\
\hline
\end{tabular}

a (from Miller et al., 1982).

Spiroplectammina spectabilis has its LO earlier on the Labrador Margin than in Hole 647A, as mentioned above. The planktonic species Pseudohastigerina micra also extends to younger levels in Hole $647 \mathrm{~A}$, but this may be a function of poorer preservation of calcareous microfossils or the larger sieve used to process samples from exploration wells. The LO of P. micra, nevertheless occurs about 2 m.y. earlier in the Labrador Sea than in low-latitude sites, and thus cannot be used as a reliable planktonic datum event in high latitudes.

Of the benthic microfossil extinction events in Figure 8, only A. latus, Ammobaculites aff. polythalamus, Ammosphaeroidina sp. 1, and Karreriella conversa plot near a best-fit line. This suggests that these taxa are isobathyal and that their extinction events can be used for correlation at different paleodepths.

\section{PALEOECOLOGY AND PALEOCEANOGRAPHY}

\section{Benthic Foraminifers and the Burial History of the Labrador Shelf and Sea}

The burial history of the sedimentary wedge along the Labrador Margin and in the deep Labrador Sea is strongly influenced by the tectonic history of the region. The geologic record on the margin shows three phases of sedimentation:

1. A rifting phase before Anomaly 34 of mid-Cretaceous age (Fig. 9, North Leif I-05 well).

2. A seafloor spreading phase between Chrons C34 and C13 (Campanian-Maestrichtian to earliest Oligocene age).

3. A late Paleogene to Neogene Neotectonic phase.

Gradstein and Srivastava (1980) were the first to draw attention to this relatively simple subsidence and sedimentation pattern as illustrated by the depositional histories in several exploration wells. As reported by Gradstein and Berggren (1981), the temporal distribution of flysch-type agglutinated foraminifers on the Labrador Margin is essentially confined to the seafloorspreading phase, Maestrichtian to Eocene. This is the time when the sedimentary wedge along the margin experienced bathyal conditions, particularly along the modern shelf edge.

The occurrence of flysch-type agglutinated assemblages in selected Labrador Sea wells is shown in Figures 9 and 10. These 
COMPARISON OF LAST OCCURRENCE EVENTS

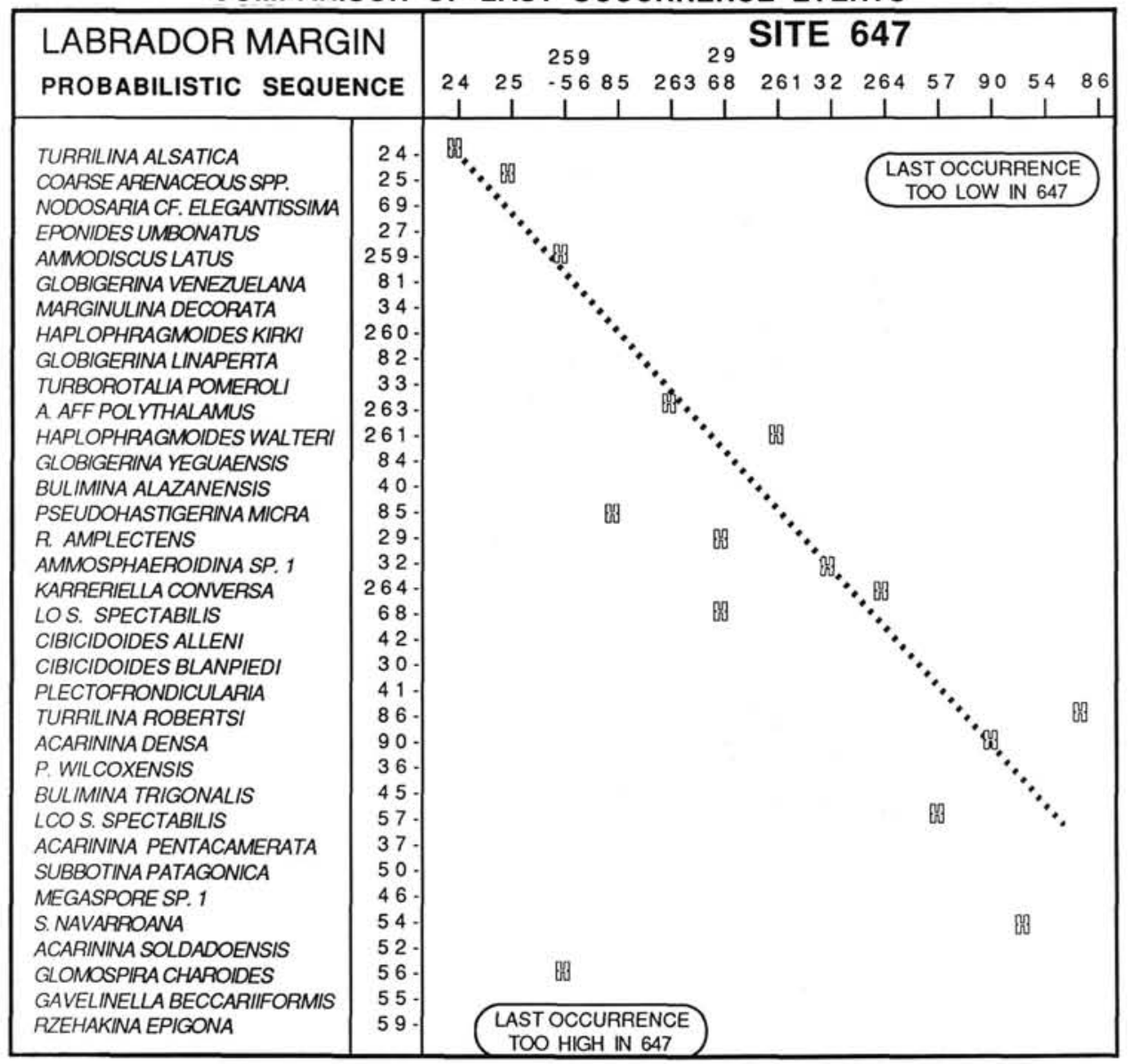

Figure 8. Comparison of microfossil extinction events in common between the probabilistic Labrador Margin sequence and that at Site 647. Numbers across the top of the scatterplot are dictionary numbers assigned to each taxon.

figures display the restored sedimentation rates and burial histories in Hole 647A and in three Labrador Margin wells (Indian Harbour M-52, North Leif I-05, and Karlsefni H-13). Restored sedimentation rate and burial calculations follow Stam et al. (1987). The interval of less diversified agglutinated assemblages coincides with the development of the late Paleocene to early Eocene Gudrid Sands, which created less favorable substrate conditions for the development and preservation of foraminifer assemblages. The disappearance of agglutinated assemblages along the Labrador Margin after the Eocene was caused by a regional trend from slope to shelf environments, accentuated by the "mid"-Oligocene lowstand in sea level.

\section{The Glomospira Facies and the NP14 Sea-Level Event}

An assemblage of exclusively agglutinated foraminifers dominated by Glomospira spp. occurs over a 20 -m interval of noncalcareous claystones, and is coincident with an increase in TOC (Fig. 2). This carbonate-free interval is evidence of a rise in the CCD in the Labrador Sea to a level above $2500 \mathrm{~m}$. The age of this assemblage is constrained by nannofossils occurring above and below, as NP13 to the lower part of Zone NP15 (CP13b) (Firth, this volume). The lithologic change from the carbonatefree interval with Glomospira (below) to calcareous sediments above also corresponds to a mid-sediment seismic reflector identified at 618 mbsf. An assemblage containing common Glomospira also occurs at the top of the lower Eocene in the Bonavista C-99 well on the Labrador Margin (Fig. 7).

In the modern Gulf of Mexico, Glomospira assemblages are present in areas of low sedimentation rates, such as on subma- rine highs (Poag, 1981). The Glomospira facies in Hole 647A also represents a period of lowered sedimentation rate $(\sim 5 \mathrm{~m} /$ m.y., assuming continuous sedimentation, compared with 37 $\mathrm{m} / \mathrm{m} . \mathrm{y}$. in the middle-late Eocene). Similar Glomospira facies are also found in the Carpathian basins in Poland (e.g., Geroch et al., 1967; Morgiel and Olszewska, 1981), and in the Tangier Unit of the Moroccan Rif Zone (Morgiel and Olszewska, 1982). In the Dulka Unit of the Polish Carpathians, the age of the Glomospira facies is constrained by nannofossil-bearing sediments above and below, as from NP12 to NP14 (Olszewska and Smagowicz, 1977). In both Poland and Morocco, the Glomospira facies is associated with reddish or variegated (red and green) shales, such as those in Hole 647A. Morgiel and Olszewska (1982) noted the remarkable similarity in species composition of this assemblage on both the northern and southern margins of the Mediterranean Tethys. The temporal coincidence of Glomospira facies in both the Atlantic and Tethys suggests a common ecological cause.

A number of important oceanographic events occur near the early/middle Eocene boundary (Fig. 11). The basal middle Eocene (Zone NP14) is a time of lowered eustatic sea level (Haq et al., 1987) and inferred increased paleoproductivity, as suggested by the presence of biosiliceous sediments in the equatorial Atlantic. Berggren and Hollister (1974) cited volcanism in the Carribean and Norwegian-Greenland Sea as a possible source of nutrients to the North Atlantic. However, carbon-isotopic evidence suggests that changes in the carbon reservoirs through influx of nutrients from the shelves are also important (Broecker, 1982). Planktonic and benthic carbon-isotope ratios display de- 

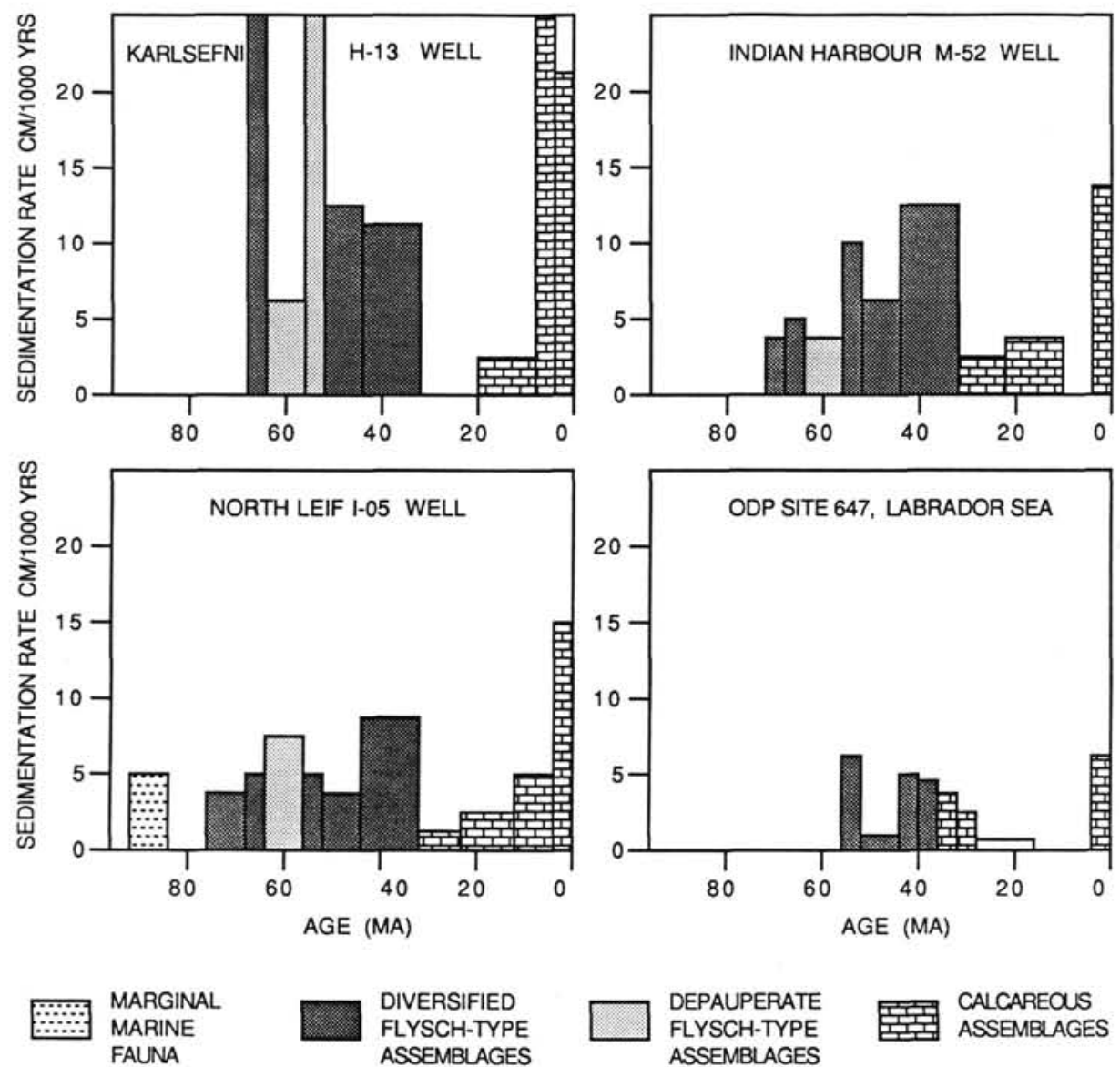

Figure 9. Benthic foraminifer assemblages and restored sedimentation rates in three Labrador Margin wells and in Hole 647A, following calculations by Stam et al. (1987).

creasing surface to bottom gradients from the early Eocene to the late Eocene (Boersma). The somewhat higher carbon isotope gradients might suggest higher nutrient contents and paleoproductivity in the early to middle Eocene. Increased TOC contents, despite lower sedimentation rates in the Glomospira facies at Site 647, increased nutrients and (presumably) decreased oxygenation of bottom water. The synecology of the assemblage is consistent with the idea of high productivity. Glomospira and Ammodiscus are regarded as epifaunal detritus feeders (Jones and Charnock, 1985), and presumably are well-adapted to take advantage of an increased amount of food particles derived from the surface layer of the ocean.

Climatic and paleoceanographic changes were coincident with the eustatic lowering of sea level in the basal Lutetian. In the Atlantic, surface waters cooled approximately $1^{\circ} \mathrm{C}$ and deep water cooled about $2^{\circ} \mathrm{C}$ across the early/middle Eocene boundary (Boersma et al., 1987). At the same time, the proto-Gulf Stream flow intensified, possibly due to restriction of the circum-global current in the Carribean (Tucholke and Mountain, 1986), and an east-west gradient was established among planktonic foraminifer faunas (Boersma et al., 1987), indicating intensification of the Atlantic subtropical gyres. The increased circulation that accompanied eustatic decrease in sea level is a likely cause of numerous hiatuses encompassing the early/middle Eocene boundary at DSDP Sites in the western North Atlantic (Poag, 1987) and at bathyal depths on the Goban Spur (Poag et al., 1985), Rockall Margin (Tucholke and Mountain, 1986), and Labrador Margin-Northern Grand Banks (Gradstein, 1987; Fig. 6). Among benthic foraminifers, there appears to be a reduction in numbers of Bulimina and an increase in Nuttallides truempyi across the Ypresian/Lutetian Boundary in the western North Atlantic (Poag and Low, 1987) as well as in the Labrador Sea. Miller et al. (1987) ascribed the eustatic fluctuations in sea level in the pre-late Eocene to global tectonic and seafloorspreading rate changes. For example, in the North Atlantic, seafloor-spreading rate changed from $\sim 21 \mathrm{~mm} / \mathrm{yr}$ to $\sim 9 \mathrm{~mm} / \mathrm{yr}$ between anomaly 21 and 22 (Srivastava, 1978), and in the Labrador Sea a decrease in spreading rate from $7.5 \mathrm{~mm} / \mathrm{yr}$ to $\sim 2$ $\mathrm{mm} / \mathrm{yr}$ occurred between anomaly 20 and 21 (S. Srivastava, pers. comm. to MAK, 1987).

Carbon-isotopic evidence at Walvis Ridge Site 357 (Boersma et al., 1987), points to some nutrient-poor deep-water production in the early middle Eocene. Benthic foraminifers record $\delta^{13} \mathrm{C}$ ratios of $\sim 0.5 \%$ in Zone $\mathrm{P} 10$, compared with values of about $-0.1 \%$ in the early Eocene (Boersma et al., 1987). The source of the deep water, however, is still a matter of debate. During the basal Lutetian lowstand in sea level, marine connections between the Atlantic and the Norwegian-Greenland Sea were temporarily interrupted, allowing the trans-Atlantic migration of terrestrial faunas (McKenna, 1983). Berggren and Olsson (1986) noted that the opening of surface connections between the Arctic Ocean and the Norwegian-Greenland Sea in the early middle Eocene may have been a source of protoNADW. However, the presence of warm-temperate early Eocene floras and faunas in northern high latitudes (Schweitzer, 1980; Wolfe, 1980; Estes and Hutchison, 1980) would argue against outflow from the Norwegian-Greenland Sea being very cold. Annual mean early Eocene temperature in Spitsbergen has been estimated as between $15^{\circ}$ and $18^{\circ} \mathrm{C}$ (Schweitzer, 1980). Winter temperatures must have been mild, since the fossil flora con- 

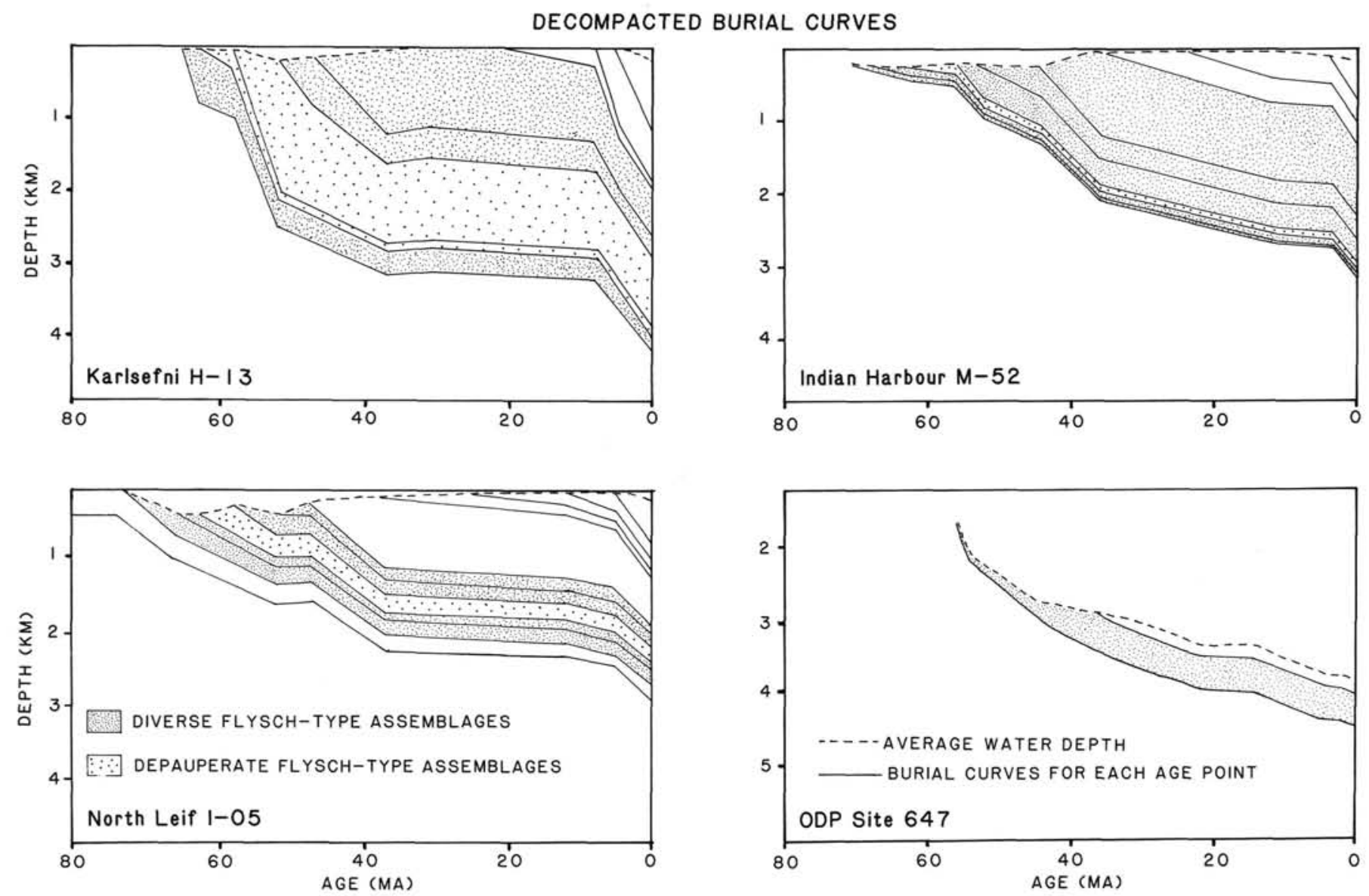

Figure 10. Burial history of the sedimentary wedge in three Labrador Margin wells and at Site 647, following calculations by Stam et al. (1987).
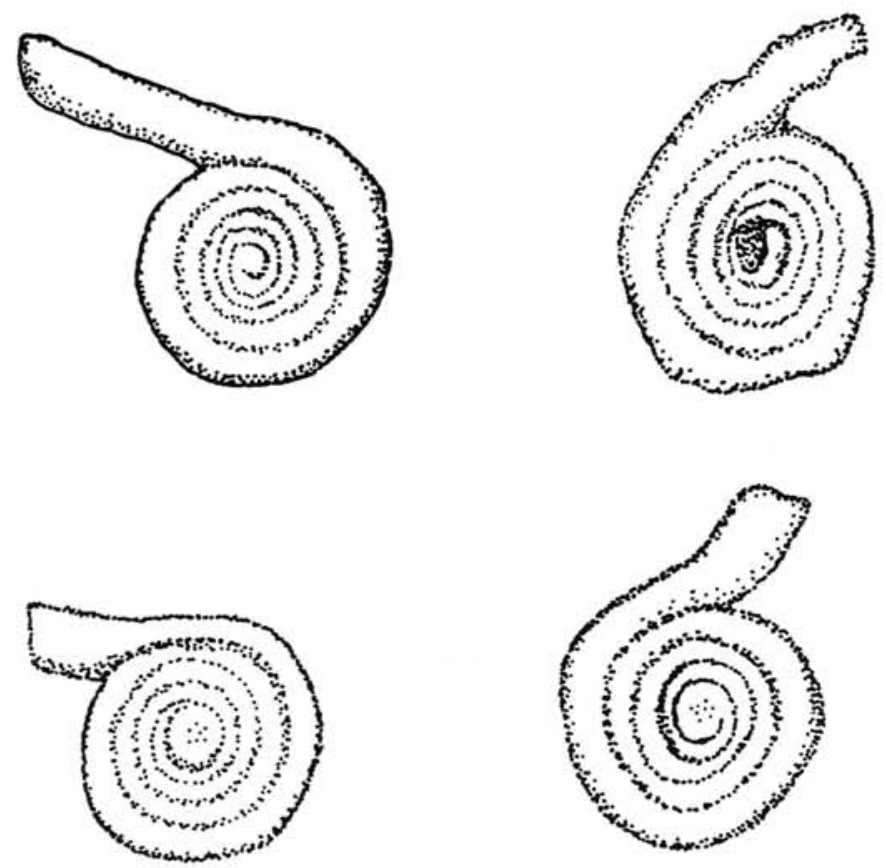

Figure 11. Paratypes of Ammodiscus nagyi n.sp. from Sample 105$647 \mathrm{~A}-66 \mathrm{R}-3,57-60 \mathrm{~cm}$. Camera lucida drawings, X225. tains species that do not tolerate frosts (Schweitzer, 1980; M.J. Head, unpubl. data).

Berggren and Schnitker (1983) postulated a northward flow of cool water from the South Atlantic, based on a comparison of oxygen-isotopic evidence. Carbon-isotopic evidence from Hole $647 \mathrm{~A}$ lends support to the idea of a southern source of nutrientdepleted deep water. Benthic $\delta^{13} \mathrm{C}$ ratios at Site 647A average about $-0.5 \%$ (Arthur et al., this volume). These values are about $1 \%$ lighter than the age-equivalent values recorded at Site 367 but may reflect diagenetic overprints. Poag (1987) places the onset of significant thermohaline circulation in the North Atlantic as early as the Paleocene/Eocene boundary, before the opening of the Norwegian-Greenland Sea. However, recent oxygen-isotopic evidence indicates that cooling near Antarctica may have resulted in deep-water production as early as the Late Cretaceous (Barrera et al., 1987).

\section{Agglutinated Foraminifers and the Eocene/Oligocene Boundary}

Site 647 is unique because no other DSDP site in the North Atlantic contains assemblages of flysch-type agglutinated foraminifers in an Eocene-Oligocene section. Agglutinated foraminifers from middle Eocene to early Oligocene sediments in Hole 647 A display a reduction in abundance, a reduction in size, and a decrease in diversity as the flysch-type taxa underwent a series of extinctions and local pseudoextinctions over a period of 5 m.y.. There is a cluster of LO events near the Eocene/Oligocene boundary, when about 10 species disappeared within a span of about 0.5 m.y. With the exception of two species, the flyschtype taxa disappeared from the deep Labrador Sea by the end of 
Zone NP21. The disappearance of flysch-type taxa was essentially completed below the increase in biogenic silica concentrations and the position of the R4 seismic reflector at 240 mbsf.

Unlike at other DSDP sites in the North Atlantic, the Eocene/Oligocene boundary at Site 647 is not delineated by a hiatus or any obvious lithologic change. The abundance of biosiliceous components and TOC increases from late Eocene to the early Oligocene; therefore there is no evidence of oligotrophic conditions observed in other areas of the North Atlantic. The basal Oligocene acme of Nuttallides umbonifera, however, displays similarities with coeval assemblages from the Bay of Biscay (Miller, 1983) and the equatorial Pacific (Corliss, 1979).

The sequence of LOs of taxa is shown in Figure 4. Among agglutinated foraminifers, LOs began at an increased rate near the boundary between the middle and late Eocene. The first group of species to disappear are agglutinated taxa with walls composed of small planktonic foraminifer tests, such as Psammosphaera testacea and a species of Rhizammina. Small elongate forms, such as Karreriella conversa, Bigenerina sp., Reophax guttifer, and Karreriella coniformis, and the delicate species, such as Hormosina distans, Hyperammina subnodosiformis, and Hyperammina kenmilleri n.sp. were also among the first forms to disappear in the late Eocene. However, some of these LOs are local extinctions, since $K$. conversa, $P$. testacea, and $R$. guttifer, and $H$. distans are all found in the modern North Atlantic. Near the Eocene/ Oligocene boundary, the species that disappeared were mainly lituolids and species that presumably share an epifaunal habitat, such as Glomospira serpens, Trochammina, and Saccammina.

About 10 species of flysch-type taxa survived the Eocene/ Oligocene boundary. These are either robust forms, such as Rhabdammina, Ammodiscus latus, and Cribrostomoides, or species with smooth, well-cemented tests, such as Ammodiscus cretaceous, Bathysiphon, or Glomospira charoides. Interestingly, more than one-half the surviving species are ammodiscids or similarly coiled forms (Spirosigmoilinella). Such species are epibenthic detritus feeders, according to Jones and Charnock (1985), but the community still contains a mix of infaunal species (Reophax subnodulosus) and suspension feeders (Rhabdammina and Bathysiphon). Therefore, there is no obvious change in the synecologic structure of the assemblage, as observed in the Miocene drift sediments at Site 646 (Kaminski et al., this volume).

The disappearance of agglutinated taxa near the Eocene/Oligocene boundary in Hole $647 \mathrm{~A}$ suggests a change in water mass properties as a primary cause. Delicate species disappeared first, indicating that the faunal turnover may be at least partly attributed to preservational factors. Therefore, this observation is consistent with the "old bottom-water model" of Gradstein and Berggren (1981). Although carbon $\delta^{13} \mathrm{C}$ values in Hole 647A show no consistent trend with depth, the Eocene Cibicidoides values are light (mean $=-0.55 \%$.), which may suggest the presence of comparatively "old," nutrient-rich bottom water (Arthur et al., this volume). Although there is no benthic isotopic data for the Oligocene of Hole 647A, data from Sites 558 and 563 (Miller and Fairbanks, 1985) indicate the presence of "young," nutrient-poor water in the eastern North Atlantic between 36 and $33 \mathrm{Ma}$. Thus, we suspect that increased oxygenation of deep water resulted in increasingly poorer preservation of agglutinated foraminifers observed in Hole 647A.

\section{Paleoceanographic Significance of Flysch-Type Assemblages}

The disappearance of agglutinated foraminifers in the deep Labrador Sea near the Eocene/Oligocene boundary has been attributed to changes in water mass properties associated with the onset of vigorous thermohaline circulation in the North At- lantic (Miller et al., 1982). Typical bottom-water temperatures cooled from about $6^{\circ}-10^{\circ} \mathrm{C}$ in the late Eocene to temperatures similar to modern bottom water in the earliest Oligocene (Miller et al., 1987). At the same time, the Atlantic carbon-isotope values begin to diverge from mean ocean water near the Eocene/ Oligocene boundary. A comparison of Atlantic benthic carbonisotope records with those of the Pacific indicates a maximum supply of nutrient-depleted bottom water between 36 and $34 \mathrm{Ma}$ (Miller and Fairbanks, 1985; Miller and Katz, 1987a). The source of the cool, nutrient-depleted deep water in the early Oligocene was reported by Miller and Tucholke (1983) as Iceland-Scotland Ridge Overflow Water, analogous to the modern North Atlantic. Therefore, we need to look to the Norwegian-Greenland Sea for the ultimate cause of the Eocene-Oligocene faunal turnover at Site 647.

Berggren and Schnitker (1983) noted that the opening of a deep channel through the Fram Strait between Greenland and Spitsbergen during Chronozone 13 probably allowed cold water from the Arctic to enter the Norwegian-Greenland Sea, and from there, to enter the North Atlantic. However, this arctic water was most likely not as dense as the deep water already present in the deep Norwegian-Greenland Sea. Deep sites in the Lofoten Basin and at the base of the Vøring Plateau contain agglutinated foraminifer assemblages throughout the Oligocene, indicating a stable, stratified water column. Shallow sites on the Vøring Plateau, however, display a faunal turnover from agglutinated assemblages in the Eocene to predominantly calcareous assemblages in the Oligocene. Agglutinated foraminifers also disappear near the Eocene/Oligocene boundary in exploration wells from the Beaufort Sea (Young and McNiel, 1983). Thus, if arctic water was the cause of this faunal turnover, the water mass may have been analogous to present-day polar water, which is present in the Norwegian-Greenland Sea to a depth of $150 \mathrm{~m}$ (Johannessen, 1986). Since there most likely was no connection with the Atlantic through the Denmark Straits until the mid-Miocene (Thiede and Eldholm, 1983), polar water flowing south along the east coast of Greenland would have turned east at the Greenland-Scotland Ridge to recirculate through the NorwegianGreenland Sea.

An alternative scenario exists that may account for the disappearance of agglutinated foraminifers in the shallow NorwegianGreenland Sea. Agglutinated foraminifers also disappear near the Eocene/Oligocene boundary in exploration wells from the Viking Graben (Kaminski and Gradstein, 1987). The outflow of water through the Faeroe-Shetland Channel must be volumetrically balanced by the inflow of eastern Atlantic surface water, as it is today (Worthington, 1970). Return flow to the NorwegianGreenland Sea would have existed through the Faeroe-Shetland Channel and through the North Sea via the English Channel. Therefore, Atlantic water may have been present over the Vøring Plateau in the early Oligocene. This Atlantic water would have circulated along the eastern margin of the basin through the Greenland-Spitsbergen Channel and into the Arctic Ocean. The first possible evidence for the advection of Atlantic water into the Norwegian-Greenland Sea was Müller's finding (1976) of an abundant and diverse "mid"-Oligocene nannoflora on the Vøring Plateau. Unfortunately, microfossil data near the Eocene/Oligocene boundary still lack sufficient documentation. There is evidence of migration of the benthic taxon Spirosigmiolinella from the North Atlantic into the Norwegian-Greenland Sea around this time. This migration may be related to water mass changes. Spirosigmoilinella first appears near the middle/late Eocene boundary at Site 647, as well as at Site 612 in the North Atlantic (Miller and Katz, 1987b). In the North Sea, this taxon can be seen first in the late Eocene (Gradstein et al., 1988), but in the Norwegian-Greenland Sea sites, its FO is in the early Oligocene. The addition of warm saline water into the Arctic realm 
may have affected the density structure of the surface layer, thereby causing faunal changes at neritic to upper bathyal depths. However, the Atlantic vs. polar water models of faunal change remain to be tested micropaleontologically using benthic and planktonic microfossils at the Vøring Plateau and in the Beaufort Sea.

At first glance, the disappearance of flysch-type taxa near the Eocene/Oligocene boundary in the Labrador Sea and in shallow Vøring Plateau sites suggests an oceanographic link between the regions. Miller et al. (1982), Berggren and Schnitker (1983), and Tucholke and Mountain (1986) favored the production of northern-source deep water as the cause of the faunal turnover in the deep Labrador Sea. However, northern-source deep water may not have been the universal cause of the disappearance of the flysch-type faunas in the Northern Hemisphere. The paleogeographic distribution of flysch-type assemblages in the North Atlantic suggests that a southern source of deep water may have contributed to the disappearance of the North Atlantic assemblages in the early Paleogene (Kaminski and Gradstein, 1987). In the North Atlantic the LCO of flysch-type assemblages displays a diachronous pattern with latitude and depth. In the western basin, agglutinated foraminifers first disappeared from deep, equatorial sites in the late Maestrichtian, but continued into the Paleocene on the margins and in the eastern basin. Flysch-type assemblages disappeared from Site 647 and the Carpathian flysch basins near the Eocene/Oligocene boundary, but persisted at bathyal depths on the Labrador Margin and in the central North Sea into the Oligocene.

The approximately coeval disappearance of flysch-type assemblages in the North Atlantic and Carpathian flysch basins cannot be attributed to northern-source deep water in the latter region. The basal Oligocene lowstand in sea level interrupted connections between the North Sea and the northern Tethys through the Polish-Danish trough, allowing the immigration of Asian vertebrate faunas into western Europe (Cavelier et al., 1981). Deep water in the eastern Tethys may have been derived from a southern source, judging from the distribution of hiatuses along the western margin of the Indian Ocean (Kennett, 1977; Davies and Kidd, 1977). Shackleton and Kennett (1975) attributed the Eocene/Oligocene cooling of deep waters and increased deep circulation throughout the southern oceans to seaice formation near Antarctica. The increasing production of well-oxygenated, northern and southern sources of deep waters at the end of the Eocene, and the basal Oligocene lowering of sea level, resulted in a deepening of the oceanic lysocline throughout most of the world ocean, including the Tethyan flysch basins (Van Couvering et al., 1981). These events may have led to the extinction of flysch-type assemblages in the North Atlantic and Tethys. However, the shallow Greenland-Scotland Ridge prevented the exchange of deep Arctic and Atlantic water below sill depth in the Norwegian-Greenland Sea, and this area served as a refuge for flysch-type faunas until the late Neogene. This scenario for the disappearance of flysch-type faunas at the Eocene/Oligocene boundary still remains to be tested with microfossil paleobiogeographic data.

\section{CONCLUSIONS}

The recovery of a continuous section of early Eocene to early Oligocene sediments at Site 647 and the establishment of a multiple planktonic microfossil biochronology allowed us to correlate the benthic foraminifer stratigraphy of the deep Labrador Sea to a standard time scale. The Paleogene foraminifers from Site 647 were subdivided into seven assemblages, based on the stratigraphic ranges of important taxa. This subdivision of benthic foraminifer assemblages can also be recognized at DSDP Site 112 and allows us to correlate the two sites precisely. Four of the assemblages (Abyssammina-Dendrophrya, Nuttallides truempyi, Reticulophragmium amplectens, and Turrilina alsatica) correlate with standard stages (early, middle, and late Eocene and early Oligocene). Periods of increased faunal turnover and opportunistic increases in dominance of individual taxa correlate with stage boundaries, and accordingly, the remaining three assemblages (Glomospira, Spirosigmoilinella $-S$. spectabilis, and Ammodiscus latus-T. alsatica) are of shorter duration. The Ypresian/Lutetian boundary is present within a 20-m interval of noncalcareous claystones containing a Glomospira facies made up of only agglutinated taxa. The middle/late Eocene boundary is characterized by an acme of Spiroplectammina spectabilis and the FO of S. cubensis and Spirosigmoilinella. The largest cluster of LOs occurs near the Eocene/Oligocene boundary, which is delineated by the disappearance of about 12 species of flyschtype taxa and an acme of Nuttallides umbonifera. However, the faunal change from an Eocene agglutinated assemblage to an Oligocene calcareous assemblage is by no means abrupt and takes place over a period of about $4 \mathrm{~m}$.y.

Two of the four prominent mid-sediment seismic horizons recognized at Site 647 correspond to benthic assemblage boundaries. The boundary between the Glomospira facies and the overlying calcareous claystones with a Nuttallides truempyi Assemblage corresponds to an intra-Eocene seismic horizon and correlates approximately with the basal Lutetian. The presence of the Glomospira facies at Site 647 is ascribed to paleoceanographic changes caused by the basal Lutetian lowstand in sea level. The regional seismic reflector R4 occurs approximately 50 $\mathrm{m}$ above the Eocene/Oligocene boundary and corresponds to a lithologic change from calcareous claystones to porous siliceous diatomite above. This reflector correlates approximately with the boundary between the Ammodiscus latus-Turrilina Assemblage and the T. alsatica Assemblage and the LCO of flyschtype taxa.

Comparison of benthic foraminifer extinction events from Site 647 with the Labrador Margin reveals a number of similarities. The LOs of Turrilina alsatica, Ammodiscus latus, Haplophragmoides walteri, Ammosphaeroidina sp., and Spiroplectammina navarroana occur in the same order on the Labrador Margin and in the deep Labrador Sea, which confirms the utility of these taxa for regional stratigraphy. However, some forms display diachronous LOs with depth. Glomospira disappeared in the early Eocene in most Labrador Margin wells, but continued into the early Oligocene at Site 647 . The species $R$. amplectens and $S$. spectabilis disappeared at the Eocene/Oligocene boundary at Site 647 , but their LOs are earlier on the Labrador Margin.

The transition from a predominantly agglutinated assemblage in the Eocene to a calcareous assemblage in the Oligocene is attributed to the increasingly poorer preservation of agglutinated taxa. The temporal coincidence of this faunal turnover in Site 647, the shallow Vøring Plateau, the Viking Graben, and the Beaufort Sea suggests a common oceanographic link among the regions. At Site 647, the turnover is attributed to the increasing influence of cool, nutrient-poor, deep waters associated with the onset of thermohaline circulation. However, the possible oceanographic causes of this faunal change in the high-latitude basins and Carpathian flysch troughs remain to be investigated.

\section{ACKNOWLEDGMENTS}

This study was supported through grants from the Texas A\&M Research Foundation/U.S. Scientific Program (1892-B05). M. Kaminski was also supported by grants from the Geological Society of America (86-3599) and the Margaret M. Patterson Memorial Scholarship Fund. This is a contribution of the Deep Water Benthic Foramaminifer Project, which is conducted by W.A. Berggren and colleagues at the Woods Hole Oceanographic Institution and is sponsored by a consortium of oil companies (Atlantic Richfield, British Petroleum, Chevron-Gulf, ElfAquitane, Exxon, Mobil, Phillips, Shell Int., Shell USA, Standard Oil of Ohio, Texaco, and Union Oil Co. of California). 
We thank the Ocean Drilling Program for the opportunity to participate during Leg 105 and for providing samples. Various aspects of this study benefited from discussions with M. Arthur, J. Firth, S. Geroch, M. Head, G. Jones, K. Miller, J. Nagy, S. Srivastava, B. Tucholke, and J. Zachos. Amy Pallant provided much appreciated technical assistance. M. Arthur, S. Geroch, M. Head, G. Jones, D. Lazarus, S. Srivastava, and V. Williams kindly reviewed the manuscript. This is contribution No. 6548 of the Woods Hole Oceanographic Institution.

\section{REFERENCES}

Barrera, E., Huber, B. T., Savin, S. M., and Webb, P. N., 1987. Antarctic marine temperatures: late Campanian through early Paleocene. Paleoceanography, 2:21-47.

Berggren, W. A., 1972. Cenozoic biostratigraphy and paleobiogeography of the North Atlantic. In Laughton, A. S., Berggren, W. A., et al., Init. Repts. DSDP, 12: Washington (U.S. Govt. Printing Office), 965-1001.

Berggren, W. A., and Hollister, C. D., 1974. Paleogeography, paleobiogeography and the history of circulation in the Atlantic Ocean. In Hay, W. W. (Ed), Studies in Paleo-oceanography. Soc. Econ. Paleontol. Mineral. Spec. Publ, 20:126-186.

Berggren, W. A, Kent, D. V., and Flynn, J. J., 1985. Paleogene geochronology and chronostratigraphy. In Snelling, N. J. (Ed.), The Chronology of the Geological Record. Geol. Soc. (London) Mem., 10: 141-195.

Berggren, W. A., and Olsson, R. K., 1986. North Atlantic Mesozoic and Cenozoic paleoceanography. In Vogt, P. R., and Tucholke, B. E. (Eds.), The Geology of North America, Vol. M: The North Atlantic Region. Geol. Soc. Am., 565-587.

Berggren, W. A., and Schnitker, D., 1983. Cenozoic marine environments in the North Atlantic and Norwegian-Greenland Sea. In Bott, M. H., Saxov, S., Talwani, M., and Thiede, J. (Eds.), Structure and Development of the Greenland-Scotland Ridge. NATO Conf. Ser. IV, 495-548.

Boersma, A., and Premoli Silva, I., 1986. Terminal Eocene events: planktonic foraminifera and isotopic evidence. In Pomerol, C., and Premoli Silva, I. (Eds.), Terminal Eocene Events: Amsterdam (Elsevier), 213-224.

Boersma, A., Premoli Silva, I., and Shackleton, N. J., 1987. Atlantic Eocene planktonic foraminiferal paleohydrographic indicators and stable isotope paleoceanography. Paleoceanography, 2:287-332.

Broecker, W. S., 1982. Ocean chemistry during glacial time. Geochim. Cosmochim. Acta, 46:1689-1705.

Bukry, D., 1972. Further comments on coccolith stratigraphy, Leg 12, Deep Sea Drilling Project. In Laughton, A. S., Berggren, W. A., et al., Init. Repts. DSDP, 12: Washington (U.S. Govt. Printing Office), 1071-1084.

Cavelier, C., Chateauneuf, J. J., Pomerol, C., Rabussier, D., Renard, M., and Vergnaud-Grazzini, C., 1981. The geological events at the Eocene/Oligocene boundary. Palaeogeogr., Palaeoclimatol., Palaeoecol., 36:223-248:

Corliss, B. H., 1979. Response of deep-sea benthonic foraminifera to the development of the psychrosphere near the Eocene/Oligocene boundary. Nature, 282:63-65.

Davies, T. A., and Kidd, R. B., 1977. Sedimentation in the Indian Ocean through time. In Heirtzler, J. R., et al. (Eds.), Indian Ocean Geology and Biostratigraphy. Am. Geophys. Un., 61-85.

D'Iorio, M. A., 1986. Integration of foraminiferal and dinoflagellate data sets in quantitative stratigraphy of the Grand Banks and Labrador Shelf. Bull. Can. Pet. Geol., 34:277-283.

Estes, R., and Hutchinson, J. H., 1980. Eocene lower vertebrates from Ellesmere Island, Canadian Arctic Archipelago. Palaeogeogr., Palaeoclimatol., Palaeoecol., 30:325-348.

Geroch, S., Jednorowska, A., Ksiazkiewicz, M., and Liszkowa, J., 1967. Stratigraphy based upon microfauna in the western Polish Carpathians. Biul. Inst. Geol., 211:186-282.

Geroch, S., and Nowak, W., 1984. Proposal of zonation for the late Tithonian-late Eocene, based upon arenaceous foraminifera from the outer Carpathians, Poland. Benthos '83: 2nd Int. Symp. on Benthic Foraminifers (Pau, April 1983), 225-239.

Gradstein, F. M., 1987. Probabilistic biochronology in exploration micropaleontology. Innovative Biostratigraphic Approaches to Sequence
Analysis: New Exploration Opportunities. Gulf Coast Sect./Soc. Econ. Paleontol. Mineral. Found. 8th Annu. Res. Conf. [Selected Papers and Illustrated Abstracts], 69-74.

Gradstein, F. M., and Agterberg, F. P., 1982. Models of Cenozoic foraminiferal stratigraphy-northwestern Atlantic margin. In Cubitt, J. M., and Reymant, R. A., (Eds.), Quantitative Stratigraphic Correlation: New York (John Wiley \& Sons), 119-170.

Gradstein, F. M., Agterberg, F. P., Brower, J. C., and Schwarzacher, W. S., 1985. Quantitative Stratigraphy: (D. Reidel Publ. Co.), 1-589.

Gradstein, F. M., and Berggren, W. A., 1981. Flysch-type agglutinated foraminiferal stratigraphy and the Maestrichtian to Paleogene history of the Labrador and North seas. Mar. Micropaleontol., 6:211268.

Gradstein, F. M., Kaminski, M. A., and Berggren, W. A., 1988. Cenozoic foraminiferal biostratigraphy, Central North Sea.Proc. 2nd Int. Workshop on Agglutinated Foraminifers, Vienna, Austria, June 2328, 1986. Abh Geol., B-A41: 97-108.

Gradstein, F. M., and Srivastava, S. P., 1980. Aspects of Cenozoic stratigraphy and paleoceanography of the Labrador Sea and Baffin Bay. Paleogeogr., Paleoclimatol., Paleoecol., 30:261-295.

Grzybowski, J., 1898: Otwornice pokladow naftonosnych okolicy Krosna. Rozprawy Akademii Umiejetnosci w Krakowie. Wydzial Mat-Przyr. Ser., 2(33):257-305.

Hanzlikova, E., 1983. Paleogene stratigraphy and foraminifera of the Outer Flysch Belt. Knihovnicka Zemniho Plynu Nafty, 4:43-70.

Haq, B. U., Hardenbol, J., and Vail, P. R., 1987. Chronology of fluctuating sea levels since the Triassic (250 millions of years ago to present). Science, 1: - .

Hemleben, C., and Troester, J., 1984. Campanian-Maestrichtian deepwater foraminifers from Hole 543A, Deep Sea Drilling Project. In Biju-Duval, B., Moore, J. C., et al., Init. Repts. DSDP, 78: Washington, D.C. (U.S. Govt. Printing Office), 509-532.

Johannessen, O. M., 1986. Brief overview of the physical oceanography. In Hurdle, B. G. (Ed), The Nordic Seas: New York (SpringerVerlag), 103-128.

Jones, R. W., and Charnock, M. A., 1985. "Morphogroups" of agglutinating foraminifera. Their life positions and feeding habits and potential applicability in (paleo)ecological studies. Rev. Paleobiol., 4: 311-320.

Kaminski, M. A., 1984. Shape variation in Spiroplectammina spectabilis (Grzybowski). Acta Paleontol. Polonica, 29:29-49.

Kaminski, M. A., Gradstein, F. M., Berggren, W. A., Geroch, S., and Beckman, J.-P., 1988. Flysch-type agglutinated foraminiferal assemblages from Trinidad: Taxonomy, Stratigraphy and Paleobathymetry. Proc 2nd Int. Workshop on Agglutinated Foraminifers, Vienna, Austria, June 23-28, 1986. Abh. Geol., B-A41:155-227.

1987. Paleobiogeography of Paleogene flysch-type foraminiferal assemblages in the North Atlantic. Innovative Biostratigraphic Approaches to Sequence Analysis: New Exploration Opportunities. Gulf Coast Sect./Soc. Econ. Paleontol. Mineral. Found. 8th Annu. Res. Conf. [Select Papers and Illustrated Abstract], 85-89.

Kaasschieter, J.P.H., 1961. Foraminifera of the Eocene of Belgium. Koninkl. Belg. Inst. Natuurwet. Verh., 147:1-271.

Kennett, J. P., 1977. Cenozoic evolution of Antarctic glaciation, the circum-Antarctic Ocean, and their impact on global paleoceanography. J. Geophys. Res., 82:3843-3860:

Krasheninnikov, V. A., and Pflaumann, U., 1977. Cretaceous agglutinated foraminifera of the Atlantic Ocean off West Africa (Leg 41, Deep Sea Drilling Project). In Lancelot, Y., Seibold, E., et al., Init. Repts. DSDP, 41: Washington (U.S. Govt. Printing Office), 565580.

McKenna, M. C., 1983. Cenozoic paleogeography of North Atlantic land bridges. In Bott, M. H., Saxov, S., Talwani, M., and Thiede, J. (Eds.), Structure and Development of the Greenland-Scotland Ridge. NATO Conf. Ser. IV, 351-400.

Miller, K. G., 1983. Eocene-Oligocene paleoceanography of the deep Bay of Biscay: Benthic foraminiferal evidence. Mar. Micropaleontol., 7:403-440.

Miller, K. G., and Fairbanks, R. G., 1985. Oligocene to Miocene carbon isotope cycles and abyssal circulation changes. In Sunquist, E., and Broecker, W. S. (Eds.), The Carbon Cycle and Atmospheric $\mathrm{CO}_{2}$ : Natural Variations Archean to Present. Am. Geophys. Un. Geophys. Mono., 32:469-486. 
Miller, K. G., Fairbanks, R. G., and Mountain, G. S., 1987. Tertiary oxygen isotope synthesis, sea level history, and continental margin erosion. Paleoceanography, 2:1-19.

Miller, K. G., Gradstein, F. M., and Berggren, W. A., 1982. Late Cretaceous to early Tertiary agglutinated benthic foraminifera in the Labrador Sea. Micropaleontology, 28:1-30.

Miller, K. G., and Katz, M. E., 1987a. Oligocene to Miocene benthic foraminiferal and abyssal circulation changes in the North Atlantic. Micropaleontology, 33:97-149.

1987b. Eocene benthic foraminiferal biofacies of the New Jersey Transect. In Poag, C. W., Watts, A. B., et al., Init. Repts. DSDP, 95: Washington (U.S. Govt. Printing Office), 267-298.

Miller, K. G., and Tucholke, B. E., 1983. Development of abyssal circulation south of the Greenland-Scotland Ridge. In Bott, M. H., Saxov, S., Talwani, M., and Thiede, J. (Eds.), Structure and Development of the Greenland-Scotland Ridge. NATO Conf. Ser. IV, 549-590.

Morgiel, J., and Olszewska, B., 1981. Biostratigraphy of the Polish External Carpathians based on agglutinated foraminifera. Micropaleontology, 27:1-30.

1982. Uniformity of the Tethyan faunas from Cretaceous and Paleogene as shown by foraminifera from Morocco and Polish Flysch Carpathians. Cahiers Micropaleontol., 3:45-53.

Müller, C., 1976. Tertiary and Quaternary calcareous nannoplankton in the Norwegian-Greenland Sea, DSDP Leg 38. In Talwani, M., Udintsev, G., et al., Init. Repts. DSDP, 38: Washington (U.S. Govt. Printing Office), 589-639.

Okada, H., and Bukry, D., 1980. Supplementary modification and introduction of code numbers to the low-latitude coccolith biostratigraphic zonation (Bukry, 1973; 1975). Mar. Micropaleontol, 5:321-325.

Olszewska, B., and Smagowicz, M., 1977. Porownanie podzialow biostratygraficznych gornej kredy i paleogenu jednostki dukielskiej na podstawie otwornic planktonicznych i nannoplanktonu wapiennego. Przeglad Geol., 7:359-363.

Perch-Nielsen, K., 1972. Remarks on Late Cretaceous to Pleistocene coccoliths from the North Atlantic. In Laughton, A. S., Berggren, W. A., et al., Init. Repts. DSDP, 12: Washington (U.S. Govt. Printing Office), 1003-1070.

Poag, C. W., 1981. Ecologic Atlas of benthic foraminifers of the Gulf of Mexico. Stroudsburg, PA (Hutchinson Ross Publ. Co.), 1-174. 1987. The New Jersey Transect: Stratigraphic framework and depositional history of a sediment-rich passive margin. In Poag, C. W., Watts, A. B., et al., Init. Repts. DSDP, 95: Washington (U.S. Govt. Printing Office), 763-817.

Poag, C. W., and Low, D., 1987. Unconformable sequence boundaries at Deep Sea Drilling Project Site 612, New Jersey Transect: their characteristics and stratigraphic significance. In Poag, C. W., Watts, A. B., et al., Init. Repts. DSDP, 95: Washington (U.S. Govt. Printing Office), 453-498.

Poag, C. W., Reynolds, L. A., Mazzullo, J., and Keigwin, L. D., 1985. Foraminiferal, lithic, and isotopic changes across four major unconformities at DSDP Site 548, Goban Spur. In de Graciansky, P.C., Poag, C. W., et al., Init. Repts. DSDP, 80: Washington (U.S. Govt. Printing Office), 539-556.

Schweitzer, H. J., 1980. Environment and climate of the early Tertiary of Spitsbergen. Palaeogeogr., Palaeoclimatol., Palaeoecol., 30:297-312.

Sclater, J. G,. Meinke, L., Bennett, A., and Murphy, C., 1985. The depth of the ocean through the Neogene: In Kennett, J. P. (Ed.), The Miocene Ocean. Geol. Soc. Am. Mem., 163:1-20.

Shackleton, N. J., and Kennett, J. P., 1975. Paleotemperature history of the Cenozoic and the initiation of Antarctic glaciation: oxygen and carbon isotope analyses in DSDP Sites 277,279 , and 281. In Kennett, J. P., Houtz, R. E., et al., Init. Repts. DSDP, 29: Washington (U.S. Govt. Printing Office), 734-755.

Shipboard Scientific Party, 1987. Site 647. In Srivastava, S. P., Arthur, M., et al., Proc. ODP, Init. Repts., 105: College Station, TX (Ocean Drilling Program), - .

Srivastava S. P., 1978. Evolution of the Labrador Sea and its bearing on the early evolution of the North Atlantic. Geophys. J. Roy. Astron. Soc., 52:313-357.

Stam, B., Gradstein, F. M., Lloyd, P., and Gillis, D., 1987. Algorithms for porosity and subsidence history. Comput. Geosci., 13:-.

Thiede, J., and Eldholm, O., 1983. Speculations about the paleodepth of the Greenland-Scotland Ridge during late Mesozoic and Ceno- zoic times. In Bott, M. H., Saxov, S., Talwani, M., and Thiede, J. (Eds.), Structure and Dvelopment of the Greenland-Scotland Ridge. NATO Conf. Ser., IV:445-456.

Tjalsma, R. C., and Lohmann, G. P., 1983. Paleocene-Eocene bathyal and abyssal benthic foraminifera from the Atlantic Ocean. Micropaleontology Spec. Publ., 4:1-90.

Tucholke, B. E., and Mountain, G. S., 1986. Tertiary paleoceanography of the western North Atlantic Ocean. In Vogt, P. R., and Tucholke, B. E. (Eds.), The Geology of North America, Vol. M: The Western North Atlantic Region. Geol. Soc. Am., 631-650.

Van Couvering, J. A., Aubry, M. P., Berggren, W. A., Bujak, J. P., Naeser, C. W., and Wieser, T., 1981. The terminal Eocene event and the Polish connection. Palaeogeo., Palaeoclimatol., Palaeoecol., 36: 321-362.

Van Morkhoven, F.P.C.M, Berggren, W. A., and Edwards, A. S., 1986. Cenozoic cosmopolitan deep-water benthic foraminifera. Centres Rech. Explor.- Prod. Elf-Aquitaine Mem., 11.

Verdenius, J. G., and van Hinte, J. E., 1983. Central Norwegian-Greenland Sea: Tertiary arenaceous foraminifera, biostratigraphy and environment. Proc. 1st Workshop on Arenaceous Foraminifers, 7-9 Sept. 1981. Continental Shelf Inst. Publ., 108:173-224.

Williamson, M. A., 1987. A quantitative foraminiferal biozonation of the late Jurassic and Early Cretaceous of the East Newfoundland Basin. Micropaleontology, 33:37-65.

Wolfe, J. A., 1980. Tertiary climates and floristic relationships at high latitudes in the Northern Hemisphere. Palaeogeogr., Palaeoclimatol., Palaeoecol., 30:313-324.

Worthington, L. V., 1970. The Norwegian Sea as a Mediterranean basin. Deep-Sea Res., 17:77-84.

Young, F. G., and McNeil, D. H., 1983. Cenozoic stratigraphy of the MacKenzie Delta, Northwest Territories. Geol. Surv. Can. Bull., $336: 1-63$.

Date of initial receipt: 20 July 1987

Date of acceptance: 10 October 1988

Ms 105B-124

\section{APPENDIX}

Taxonomy and Description of New Species

Genus HYPERAMMINA Brady, 1878

Hyperammina kenmilleri Kaminski n.sp. (Pl. 1, Figs. 6, 7)

Bathysiphon sp., Miller et al., 1982. Pl. 1, Fig. 1.

Description. Test-free, delicate, elongate, cylindrical, consisting of a bulbous proloculus and long, rectilinear, tubular second chamber somewhat smaller in diameter than the proloculus. Wall agglutinated, thin, composed mainly of cement. Test is often flattened.

Remarks. This species differs from other species of Hyperammina in its minute size and thin wall possessing no visible agglutinated grains. The proloculus is often missing. Specimens often show signs of compaction.

Occurrences. Eocene of Sites 647 and 112, southern Labrador Sea.

Size. Diameter of tubular chamber does not exceed $0.1 \mathrm{~mm}$.

Type locality. Sample 105-647A-49R-1, 118-121 cm.

Holotype. USNM 181877. Pl. 1, Fig. 6.

Paratypes. USNM 181878 and 181879. Pl. 1, Fig. 7. Additional unfigured metatypes have been deposited in the micropaleontological collections of Dalhousie University (DAL-232-F), the Naturhistorische Museum Wien, and at the Smithsonian Institution.

Genus AMMODISCUS Reuss, 1862

Ammodiscus nagyi Kaminski n.sp.

(Pl. 2, Figs. 2,3; Text Fig. 11)

Description. Test-free, discoidal, with a proloculus followed by an undivided, planispirally, enrolled tubular chamber. Test is thin, flat, delicate, and has a characteristic tendency to uncoil tangentially: Coiled 
chamber increases in size very slowly. Coiling may be somewhat irregular. Megalospheric forms are made up of four to five whorls and have a large, bulbous proloculus, which may protrude above the flat surface of the coiled part. Microspheric forms are somewhat larger in diameter than megalospheric forms and are composed of six to eight whorls. Wall finely agglutinated, made up mainly of cement. Aperture at open end of tube.

Remarks. This species is characterized by its minute size and its tendency to uncoil (especially megalosphaeric forms). Uncoiling behavior is unusual for post-Paleozoic species of Ammodiscus. It differs from Ammodiscus planus Loeblich in uncoiling tendency and in possessing a coiled chamber that increases very slowly in size. Thin, minute specimens of Ammodiscus are often mistakenly referred to $A$. glabratus Cushman and Jarvis (see Kaminski et al., 1988). However, A. glabratus possesses a coiled chamber that increases in thickness very rapidly, so the test is biconcave in edge view. Ammodiscus tenuissimus Grzybowski differs in its larger size and in possessing more whorls. Ammodiscus nagyi n.sp. is perfectly flat and no doubt is one of the smallest Cenozoic species of Ammodiscus.

Occurrences. Lower Eocene to lower middle Eocene of Sites 647 and 112.

Size. Maximum diameter of paratypes: $144-182 \mu \mathrm{m}$. Diameter of tubular chamber (uncoiled part): $35-40 \mu \mathrm{m}$. Maximum diameter of chamber on coiled part: $22-31 \mu \mathrm{m}$.

Type Locality. Sample 105-647A-66R-3, 57-60 cm.

Holotype. USNM 181880. Pl. 2, Fig. 3.

Paratypes. USNM 181881 and 181882. Pl. 2, Fig. 2. Additional unfigured metatypes have been deposited in the micropaleontological collections of Dalhousie University (DAL-231-F), the Naturhistorische Museum Wien, the Jagiellonian University, Cracow (Grzybowski Collection), and at the Smithsonian Institution.

\section{Text Added in Proof}

\section{Addendum 1 (End of "Methods" Section, p. 707)}

Although sample and/or event ages are given to the nearest 100 k.y. as interpolated from the linear sedimentation rate curves, the error in these determinations varies significantly. In parts of the sequence, such as for the lower to middle Eocene sediment interval at Site 647, our interpolated ages may be in error by as much as $1 \mathrm{~m}$.y. The Site 647 age-depth curve used in this study (Srivastava, Arthur et al., 1987) also differs somewhat from the final plot illustrated in Baldauf et al. (this volume). We did not adjust our ages on the basis of the Baldauf et al. compilation. The reader should bear in mind that the slope of the Paleogene portion of the curve is based mainly on three Eocene magnetic events and is not well constrained in the upper Oligocene. The age-error estimates given in parentheses after most absolute ages reflects only the possible error in assigning a depth to a given event because of sample spacing.

\section{Addendum 2 (“Glomospira Facies" Section, p. 717)}

However, the accumulation rate of TOC is low, and the sediments are red and highly oxidized in the low sedimentation rate interval near the early/middle Eocene boundary at Site 647. Biogenic silica accumulation rates are also low (Bohrmann and Stein, this volume). Thus, it is still equivocal as to whether paleoproductivity was higher in association with the Glomospira facies. Lower fluxes of TOC to the seafloor would also favor epifaunal benthic foraminifers, rather than infaunal taxa. 


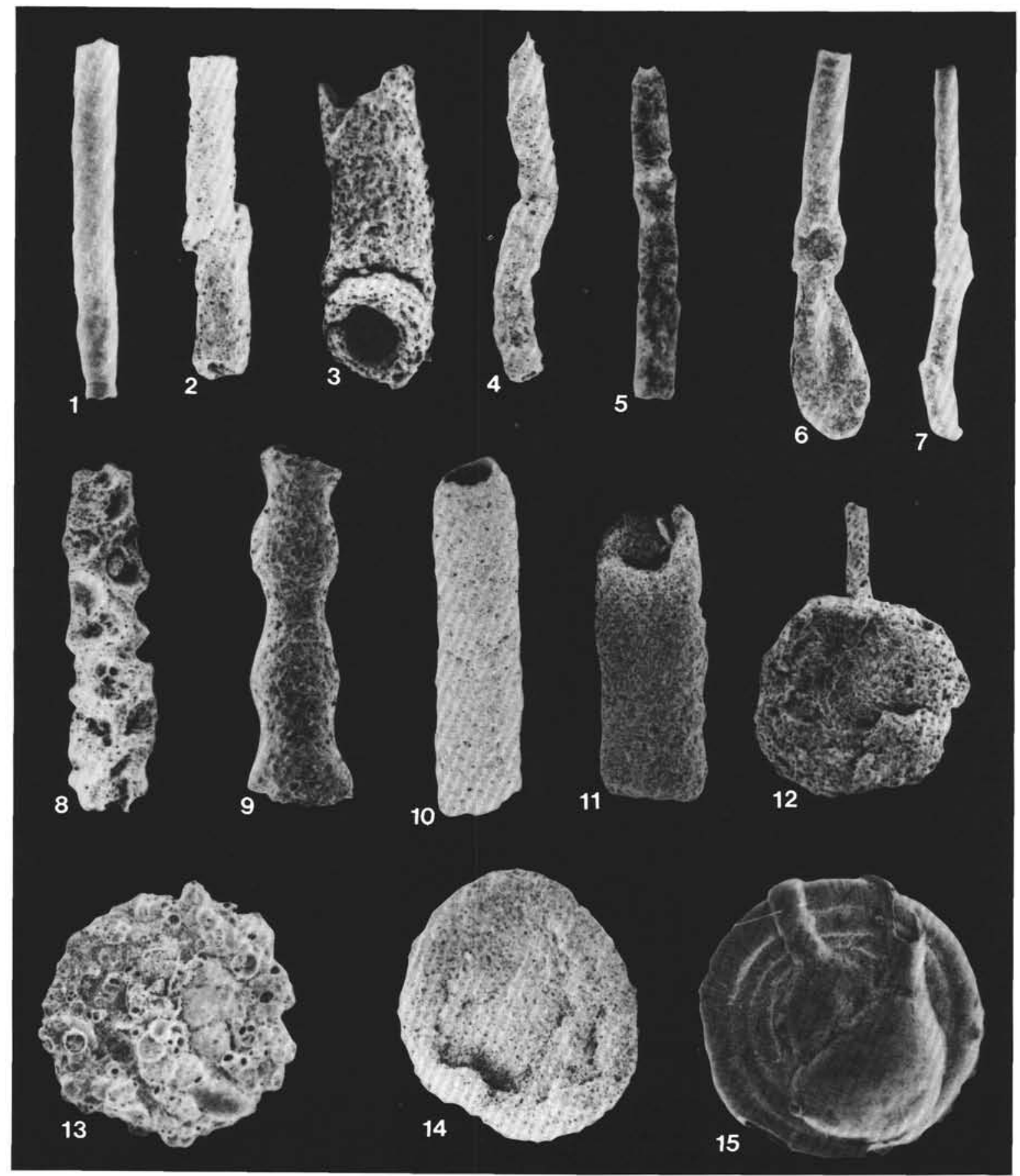

Plate 1. 1. Bathysiphon sp. (105-647A-47R-4, 74-77 cm) X50. 2. Rhabdammina sp. (105-647A-49R-1, 118-121 cm), X50. 3. Rhizammina sp. (105-647A-37R-4, 90-93 cm), X44. 4. Rhizammina sp. (105-647A-49R-I, 118-121 cm), X50. 6,7. Hyperammina kenmilleri $\mathrm{n}$. sp. (105-647A-49R$1,118-121 \mathrm{~cm}$ ); 6, X150; 7, X50. 8. Rhizammina sp. (with planktonic tests;105-647A-49R-1, 118-121 cm), X120. 9. Hyperammina ex gr. subnodosiformis (Grzybowski) (105-467A-41R-5, 58-61 cm), X83. 10,11. Dendrophrya ex gr. excelsa Grzybowski; 10, 105-647A-66R-2, 24-27 cm, X50; $11,105-647 \mathrm{~A}-67 \mathrm{R}-1,40-43 \mathrm{~cm}, \mathrm{X} 120$. 12. Saccammina complanata (Franke) (105-647A-66R-3, 57-60 cm), X137. 13. Psammosphaera testacea Flint (105-647A-68R-1, 129-132 cm), X96. 14. Aschemonella sp. (105-647A-49R-1, 118-121 cm), X60. 15. Ammolagena clavata (Jones and Parker) on a specimen of Ammodiscus cretaceous (Reuss) (105-647A-47R-4, 79-77 cm), X38. 


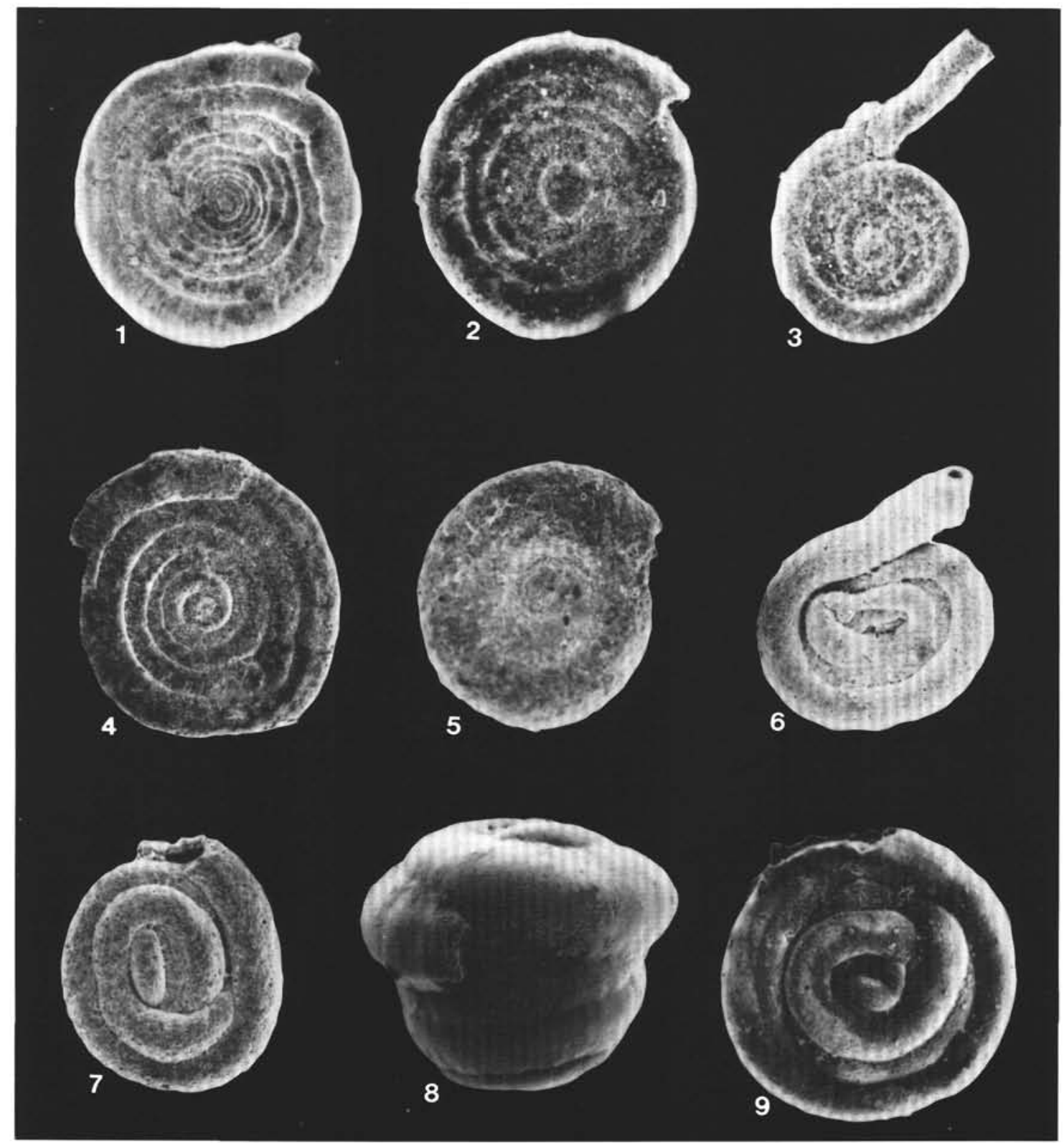

Plate 2. 1. Ammodiscus cretaceous (Reuss) (105-647A-46R-3, 60-63 cm), X38. 2,3. Ammodiscus nagyi n.sp.; 2, 105-647A-63R-3, 74-77 cm, X125; 3, 105-647A-66R-3, 57-60 cm, X150. 4,5. Ammodiscus latus Grzybowski; 4, 105-647A-51R-5, 94-97 cm; X35; 5, 105-647A-41R-1, 58-61 $\mathrm{cm}$. 6. Glomospirella sp. (105-647A-67R-1, 40-43 cm), X83. 7. Glomospira irregularis (Grzybowski) (105-647A-68R-3, 74-77 cm), X110. 8. Glomospira charoides (Jones and Parker) (105-647A-47R-4, 74-77 cm, X110. 9. Glomospira diffundens (Cushman and Renz) (105-647A-65R-2, 31$34 \mathrm{~cm},) \times 150$. 


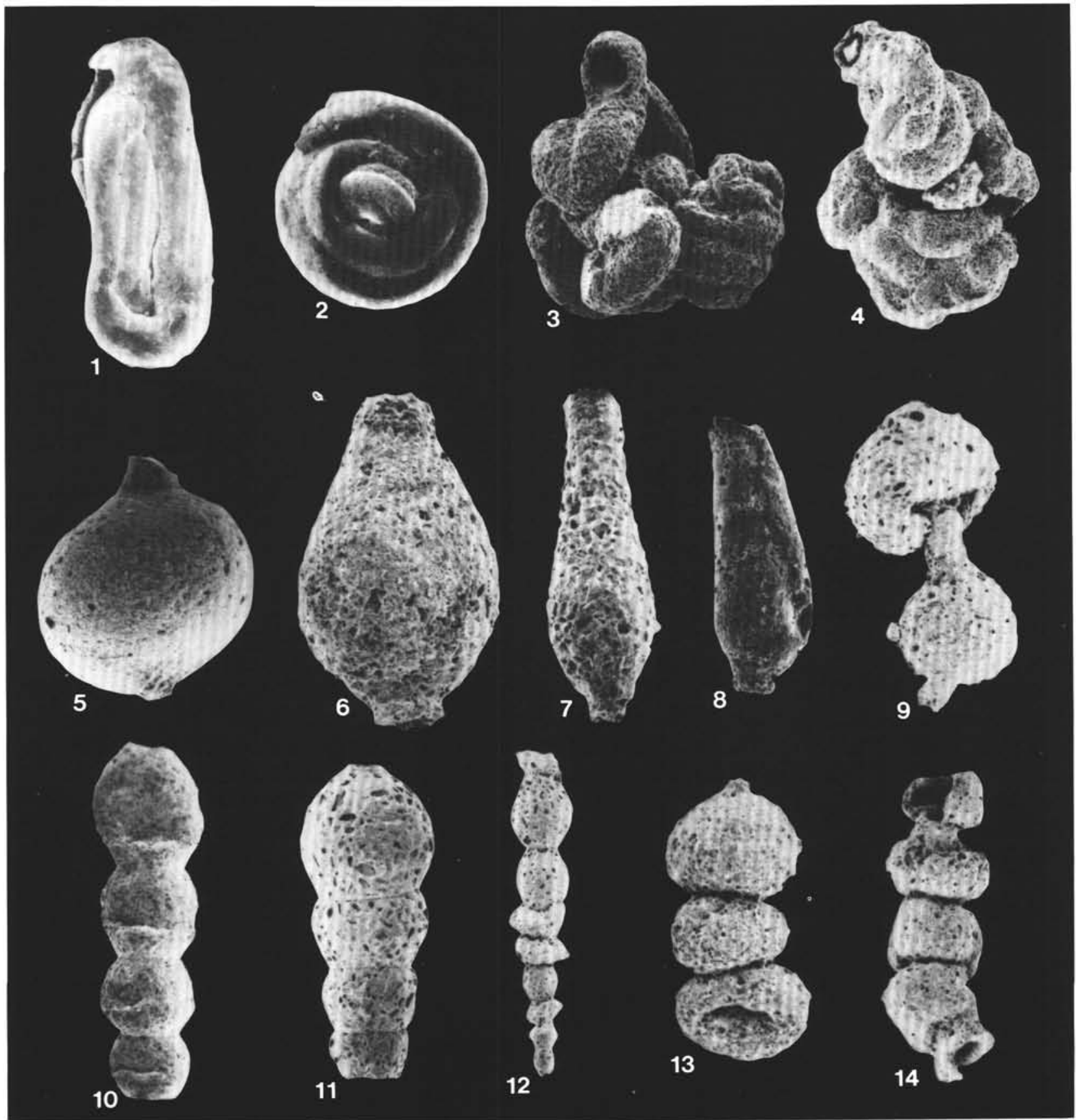

Plate 3. 1. Glomospira serpens (Grzybowski) (105-647A-42R-1, 98-102 cm), X83. 2. Glomospira gordialis (Jones and Parker) (105-647A-65R-2, 31-34 cm), X150. 3,4. Ammovertella sp. (105-647A-65R-1, 31-34 cm) X125. 5. Hormosina ovulum ovulum (Grzybowski) (105-647A-70R-2, 55$58 \mathrm{~cm}$ ) X15Q. 6. Hormosina sp. 4 (of Miller et al., 1982) (105-647A-47R-6, 52-55 cm. 7,8. Hormosina sp. aff. H. excelsa (Dylazanka); 7, 105647A-62R-1, 112-115 cm, X137; 8, 105-647A-61R, CC, X110. 9. Hormosina distans (Brady) (105-647A-62R-1, 112-115 cm) X137. 10. ?Nodellum velascoensis (Cushman) (105-647A-33R, CC) X33. 11. Reophax subnodulosus Grzybowski (105-647A-45R-1, 14-18 cm) X66. 12. Reophax sp. (105-647A-66R-3, 57-60 cm) X44. 13. Reophax pilulifer Brady (105-647A-47R-6, 52-55 cm) X96. 14. Subreophax scalaria (Grzybowski) (105647A-49R-1, $118-121 \mathrm{~cm}) \times 70$. 


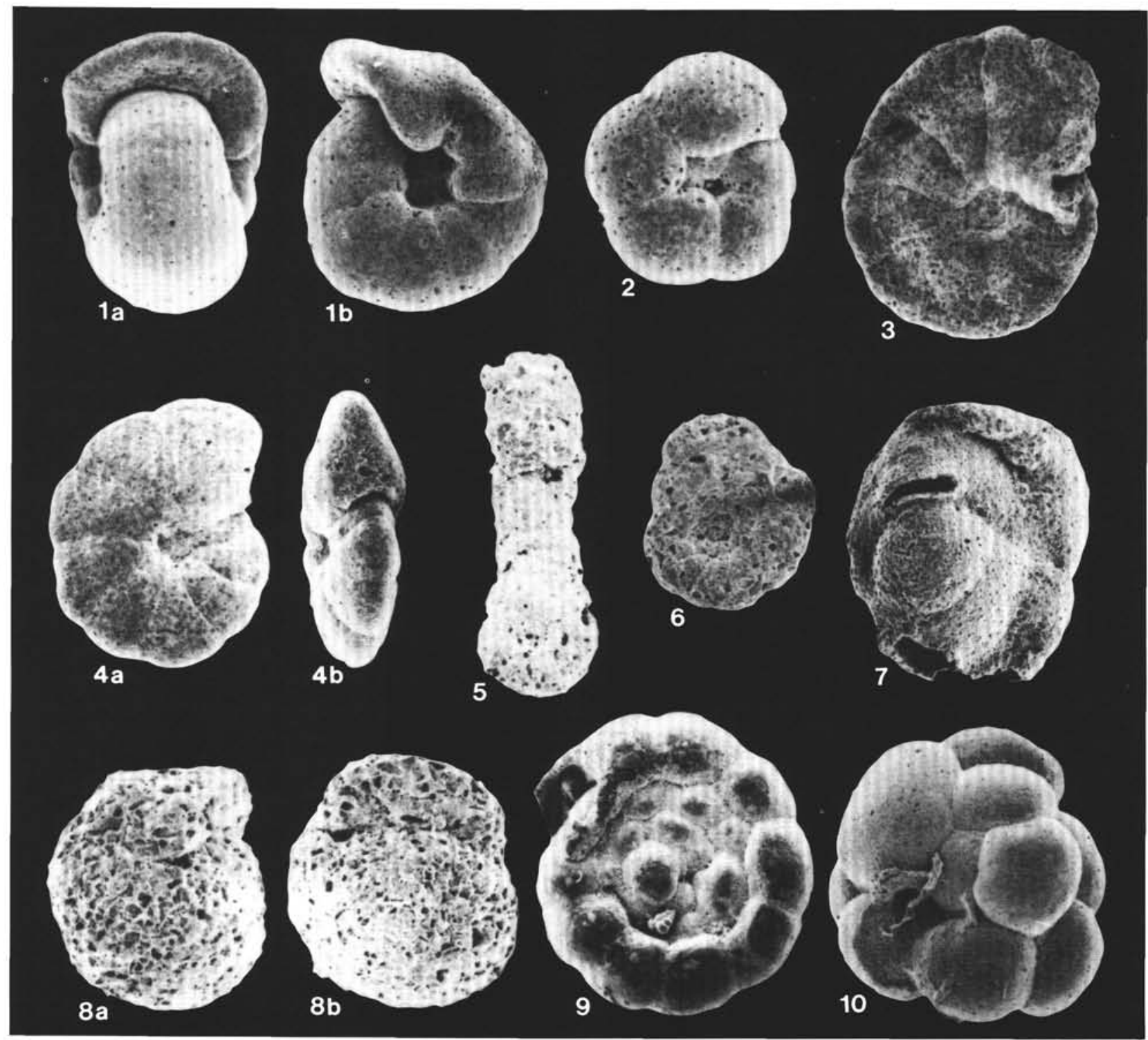

Plate 4. 1a,1b. Cribrostomoides sp. (105-647A-44R-3, 42-45 cm) X55. 2. Haplophragmoides porrectus Maslakova (105-647A-67R-3, 36-39 cm) X150: 3,4a,4b. Haplophragmoides walteri (Grzybowski); 3, 105-647A-46R-3, 60-63 cm, X96; 4a,4b, uncompressed specimen (105-647AS-47R-4, 74-77 cm) X96. 5,6. Ammobaculites aff. polythalamus (of Gradstein and Berggren, 1981); 5, 105-647A-42R-1, 98-101 cm, X110; 6, 105-647A-43R1, 95-98 cm, XllO. 7. Sphaerammina gerochi Hanzlikova (105-647A-65R-1, 31-34 cm) X137. 8a,8b. Recurvoides sp. (105-647A-49R-1, 118-121 $\mathrm{cm})$ X100. 9. Trochamminoides proteus (Karrer) (105-647A-41R-5, 58-61 cm) X38. 10. Trochamminoides irregularis White (105-647A-67R-1, 40$43 \mathrm{~cm}) \times 70$. 


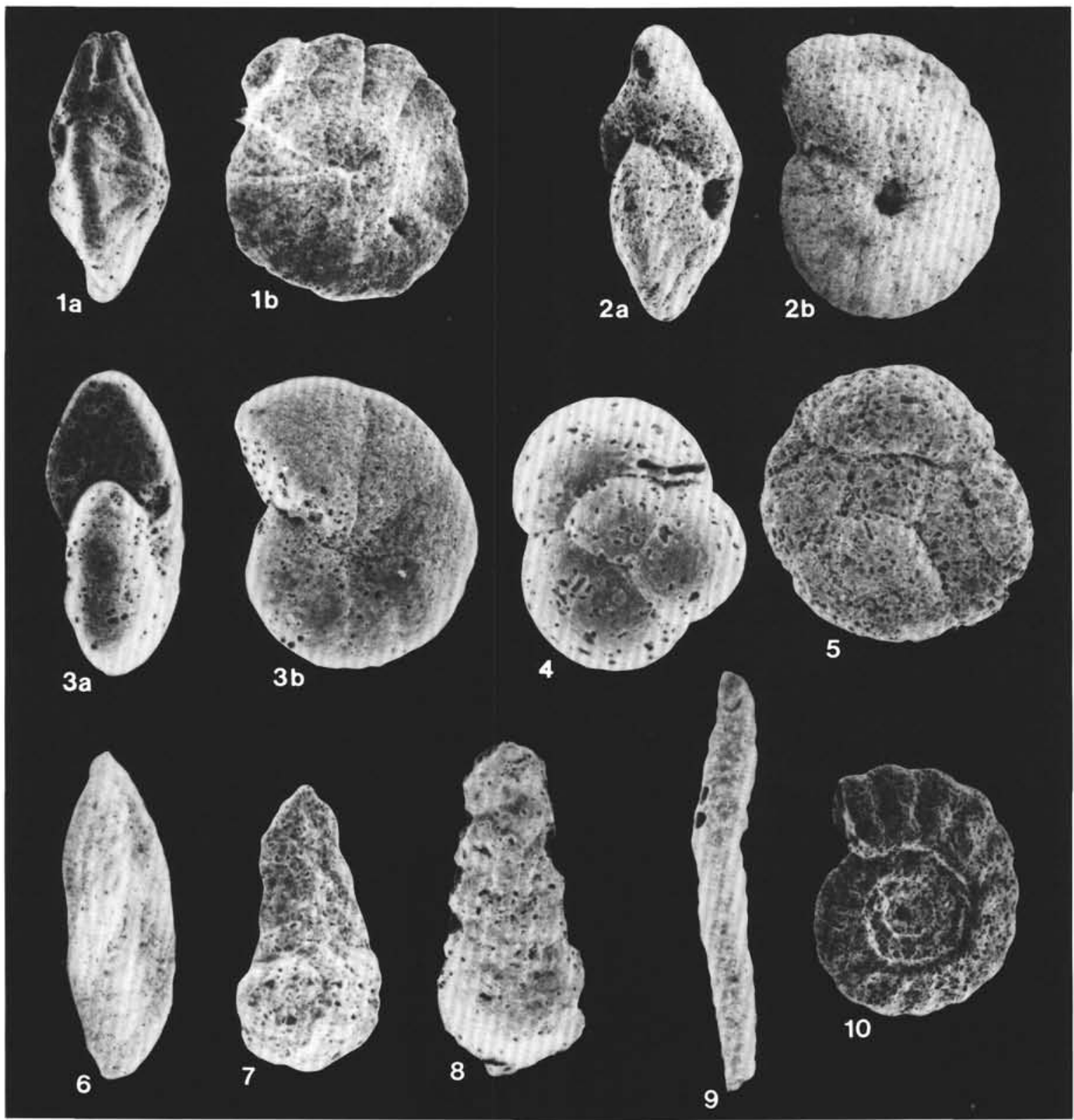

Plate 5. 1a-2b. Reticulophragmium amplectens (Grzybowski); la,1b, late Eocene morphotype, 105-647A-47R-4, 74-77 cm, X96;. 2a,2b, early Eocene morphotype, Sample 105-647A-61R, CC, X110. 3a,3b. Reticulophragmium placenta (Reuss) (105-647A-70R, CC) X83. 4. Ammosphaeroidina sp. (105-647A-47R-4, 74-77 cm) X135. 5. Trochammina deformis Grzybowski (105-647A-49R-5, 117-120 cm) X98. 6. Spirosigmoilinella compressa Matsunaga (105-647A-3R-3, 104-107 cm) X96. 7-10. Spiroplectammina cubensis (Cushman and Bermudez); 7, macrospheric specimen, 105647A-30R-2, 25-27 cm, X137; 8, macrospheric specimen, 105-647A-27R-1, 78-83 cm, X83; 9, microspheric specimen, 105-647A-33R, CC, X50; 10, microspheric specimen, 105-647A-27R-1, 78-83 cm, X137. 


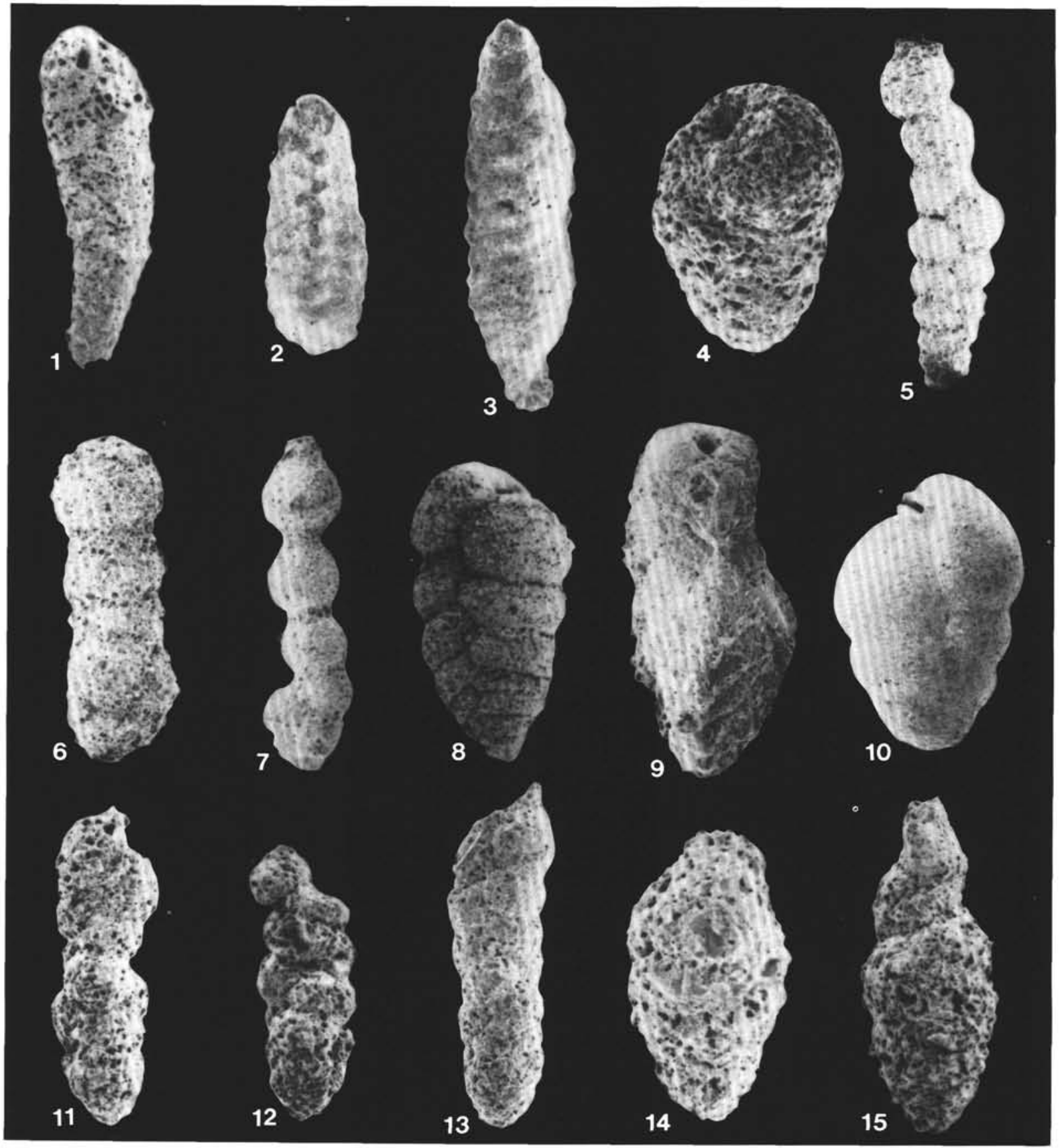

Plate 6. 1. Spiroplectammina navarroana (Cushman) (105-647A-67R-1, 40-43 cm) X96. 2,3. Spiroplectammina spectabilis (Grzybowski) (105647A-46R-1, 60-64 cm); 2, macrospheric specimen, X80; 3, microspheric specimen, X80. 4. Arenobulimina sp., (105-647A-46R-3, 60-63 cm) XllO. 5. Bigenerina sp. (105-647A-49R-5, 117-120 cm) XllO. 6,7. Clavulinoides sp.; 6, 105-647A-43R-3, 104-107 cm, X83; 7, 105-647A-68R-3, $74-77 \mathrm{~cm}$, X83. 8. Gaudryina sp. A (105-647A-30R-3, 110-113 cm) X33. 9. Gaudryina sp. B $(105-647 \mathrm{~A}-44 \mathrm{R}-3,42-45 \mathrm{~cm})$ X40. 10. Karreriella chapapotensis (Cole) (105-647A-43R-3, 104-107 cm) X83. 11-13. Karreriella conversa (Grzybowski); 11,12, 105-647A-62R-6, 22-25 cm, XllO; 13, 105-647A-62R-3, 60-63 cm, X83. 14. Karreriella coniformis (Grzybowski) (105-647A-47R-4, 74-77 cm) X98. 15. Karreriella horrida Mjatliuk (105647A-62R-6, 22-25 cm) X96. 